\title{
31. BENTHIC FORAMINIFERS AND NEOGENE BOTTOM-WATER MASSES AT DEEP SEA DRILLING PROJECT LEG 94 NORTH ATLANTIC SITES ${ }^{1}$
}

\author{
John W. Murray, Department of Geology, University of Exeter ${ }^{2}$
}

\begin{abstract}
Benthic foraminiferal assemblages from northeast Atlantic DSDP Sites 609, 610, and 611 have been interpreted with reference to modern assemblages known to be linked with the overlying bottom-water masses. It is shown that the water masses in the late Miocene to Pleistocene were similar to those of today. The distribution of the water masses changed with time, however. Antarctic Bottom Water ("AABW"), which at present is restricted to the area south of the Azores, reached as far north as the Gibbs Fracture Zone in the early Pliocene. Increased production of North Atlantic Deep Water in the late Pliocene displaced the AABW to the south. ${ }^{3}$
\end{abstract}

\section{INTRODUCTION}

One of the principal objectives of Leg 94 was to investigate the Neogene paleoceanographic history of the mid-latitude North Atlantic. Many different aspects are considered by other contributors to this volume. In this chapter, some results from a study of benthic foraminifers are used to interpret the changes in bottom-water distribution from the middle Miocene to the Recent, although only a brief survey of the Pliocene-Pleistocene glacial sequence has been possible. Sites 609,610 , and 611 were selected for study (Table 1, Fig. 1). Sites 606 and 607 are to the west of the axis of the mid-ocean ridge and therefore have not been included. Site 608 has been studied in detail by Thomas (this volume).

\section{MATERIAL AND METHODS}

Core-catcher samples from Sites 609, 610, and 611 were made available. A selection of these was studied to give representative stratigraphic coverage at each site. The samples were dried in an oven at $60^{\circ} \mathrm{C}$, then soaked in a dilute solution of calgon (sodium hexametaphosphate) until they had disintegrated. They were then washed on a $63-\mu \mathrm{m}$ sieve and the residue was dried. This was then split on a 125-mesh $(125-\mu \mathrm{m})$ sieve and only the fraction $>125 \mu \mathrm{m}$ was examined. An assemblage count of 200 or more individuals was made in all cases except those where the samples were too small to yield this number. The planktonic:benthic ratio is based on a count of $\sim 250$ individuals. Altogether, 12,745 benthic foraminifers have been mounted from the 65 samples studied. Many of the species are illustrated by Murray (1984), and a faunal reference list is given in the Appendix at the end of this chapter. The diversity is calculated by the $\alpha$-index method of Williams (1964; see Murray, 1973, p. 9, for a graph). The biostratigraphic assignments of the samples are based on the biostratigraphic sections and sedimentation curves from the site chapters (this volume).

Because of the rapid environmental changes within the glacial late Pliocene-Pleistocene section, it is impractical to study this interval from core-catcher samples. A few samples have been included just to give an indication of some of the changes.

\footnotetext{
${ }^{1}$ Ruddiman, W. F., Kidd, R. B., Thomas, E., et al., Init. Repts. DSDP, 94: Washington (U.S. Govt. Printing Office).

2 Address: Department of Geology, University of Exeter, EX4, 4QE, Devon, United Kingdom.

${ }^{3}$ See Dickson and Kidd (this volume) for an alternative interpretation of modern circulation in the northeast Atlantic.
}

Table 1. Positions of Leg 94 holes.

\begin{tabular}{lccc}
\hline \multicolumn{1}{c}{ Hole } & Latitude N & Longitude W & Water depth (m) \\
\hline $609 \mathrm{~B}$ & $40^{\circ} 52.67^{\prime}$ & $24^{\circ} 14.29^{\prime}$ & 3884 \\
$610,610 \mathrm{~A}$ & $53^{\circ} 13.30^{\prime}$ & $18^{\circ} 53.21^{\prime}$ & 2417 \\
$610 \mathrm{E}$ & $53^{\circ} 13.47^{\prime}$ & $18^{\circ} 53.69^{\prime}$ & 2445 \\
$611 \mathrm{C}$ & $52^{\circ} 53.15^{\prime}$ & $30^{\circ} 10.10^{\prime}$ & 3230 \\
\hline
\end{tabular}

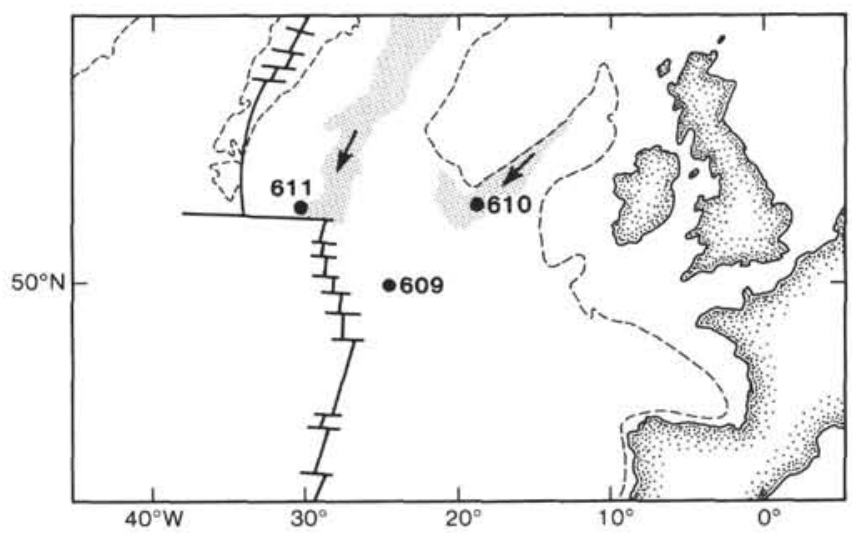

Figure 1. Positions of the three sites. Dashed line $=2000-\mathrm{m}$ isobath Lightly stippled areas $=$ drift deposits. Site 610 lies on the Feni Drift, Site 611 on the Gardar Drift.

\section{RECENT BENTHIC ASSEMBLAGES}

The modern benthic foraminiferal faunas of the North Atlantic Ocean were studied by Phleger et al. (1953). Streeter (1973) reinterpreted their results using Q-mode factor analysis. He recognized three main assemblages and was the first to demonstrate that these were related to the distribution of the bottom-water masses.

More recently, Weston has carried out a major study of northeast Atlantic benthic assemblages from depths $>2000 \mathrm{~m}$, and brief summaries of the results have been published by Weston and Murray (1984) and Murray (1984). Weston used Q-mode varimax factor analysis to interpret the results, revealing a clear correlation between assemblages and water masses (see Table 2). However, in 
Table 2. Relationships between benthic assemblages and water masses in the northeast Atlantic Ocean (from Weston and Murray, 1984).

\begin{tabular}{|c|c|c|c|c|c|}
\hline $\begin{array}{l}\text { Q-mode } \\
\text { varimax } \\
\text { factor }\end{array}$ & $\begin{array}{l}\text { Factor } \\
\text { score }\end{array}$ & Assemblage & $\begin{array}{c}\text { Variance } \\
\text { accounted } \\
\text { for }(\%)\end{array}$ & Water mass ${ }^{a}$ & Salinity $(\$ 6)$ \\
\hline 6 & $\begin{array}{l}-0.66 \\
-0.54\end{array}$ & $\begin{array}{l}\text { Globocassidulina subglobosa } \\
\text { Osangularia rugosa }\end{array}$ & 4 & NADW + MW & Variable \\
\hline 3 & -0.80 & Epistominella exigua & 18 & $\begin{array}{l}\text { Upper NADW } \\
=\text { LSW + NSOW }\end{array}$ & $34.92-34.97$ \\
\hline 5 & $\begin{array}{l}-0.71 \\
-0.39\end{array}$ & $\begin{array}{l}\text { Pullenie spp. } \\
\text { Nonionella iridea }\end{array}$ & 6 & $\begin{array}{l}\text { Middle NADW } \\
=\text { NSOW }\end{array}$ & $>35.0$ \\
\hline 1 & $\begin{array}{l}0.40 \\
0.43 \\
0.54 \\
0.43\end{array}$ & $\begin{array}{l}\text { Oridorsatis umbonatus } \\
\text { Cibicidoides kullenbergi } \\
\text { Ptanulind wuellerstorfi } \\
\text { Glabocassidulina subgiobosa }\end{array}$ & 31 & $\begin{array}{l}\text { Lower NADW } \\
=\text { NSOW + DSOW }\end{array}$ & $34.90-34.96$ \\
\hline 2 & -0.94 & Osangularia umbonifera & 17 & AABW & $<34.90$ \\
\hline
\end{tabular}

order to eliminate some of the minor factors, the results have here been computed to four factors. These account for $80 \%$ of the variance and give a very clear picture (Table 3, Fig. 2). Factors 1, 2, and 3 remain the same, and factor 4 is close to factor 6 of Table 2. Geographic distributions of factor scores $>0.5$ show discrete fields (Fig. 3). The vertical layering of the water masses can be visualized from a latitude-vs.-depth plot of the dominant factor in each sample (Fig. 4). Graphic plots of factor 1 (North Atlantic Deep Water [NADW]) against factor 3 (Antarctic Bottom Water [AABW]) and factor 1 against factor 2 (North East Atlantic Deep Water [NEADW]) show that, apart from the discrete fields for these water masses (defined by factor scores $>0.5$ ), some samples represent mixed waters, as they lie close to the center of the diagram (Figs. 5, 6).

To assess the significance of mixing, some theoretical modeling was undertaken. Typical assemblages representing NEADW (Weston's sample 117), NADW (Weston's samples 39, 40, 41, and 43 averaged), and AABW (Weston's samples 104 and 105 averaged) (J. F. Weston, personal communication, 1983) were determined. Hypothetical mixed assemblages were calculated by adding together proportions of the typical assemblages. These modeled assemblages were then subjected to varimax factor analysis in comparison with the Recent data set already discussed. The results are shown in Figure 7. The modeled mixed assemblages of NADW and NEADW plot as would be intuitively expected, but AABW is weighted more strongly by the factor analysis than perhaps it should be. For example, the $50 \%$ NADW $/ 50 \%$ AABW modeled

Table 3. Q-mode varimax factor analysis of northeast Atlantic Ocean: Recent benthic assemblages (data from J. F. Weston, personal communication, 1983).

\begin{tabular}{|c|c|c|c|c|}
\hline $\begin{array}{l}\text { Varimax } \\
\text { factor }\end{array}$ & Principal species & $\begin{array}{l}\text { Varimax } \\
\text { factor } \\
\text { score }\end{array}$ & $\begin{array}{c}\text { Variance } \\
\text { accounted } \\
\text { for }(\%)\end{array}$ & Water mass \\
\hline \multirow[t]{4}{*}{1} & Planulina wuellerstorfi & 0.51 & \multirow[t]{4}{*}{29} & \multirow{4}{*}{$\begin{array}{l}\text { North Atlantic } \\
\text { Deep Water } \\
\text { = NADW }\end{array}$} \\
\hline & Globocassidulina subglobosa & 0.49 & & \\
\hline & Cibicidoides kullenbergi & 0.40 & & \\
\hline & Oridorsalis umbonatus & 0.38 & & \\
\hline 2 & Osangularia umbonifera & -0.91 & \multirow[t]{5}{*}{17} & $\begin{array}{l}\text { Antarctic Bottom } \\
\quad \text { Water = AABW }\end{array}$ \\
\hline 3 & Epistominella exigua & -0.80 & & Upper NADW or \\
\hline & & & & North East \\
\hline & & & & Atlantic Deep \\
\hline & & & & Water $=$ NEADW \\
\hline \multirow[t]{2}{*}{4} & Cassidulina obtusa & 0.67 & \multirow[t]{2}{*}{7} & Mediterranean \\
\hline & Globocassidulina subglobosa & 0.56 & & Water \\
\hline
\end{tabular}

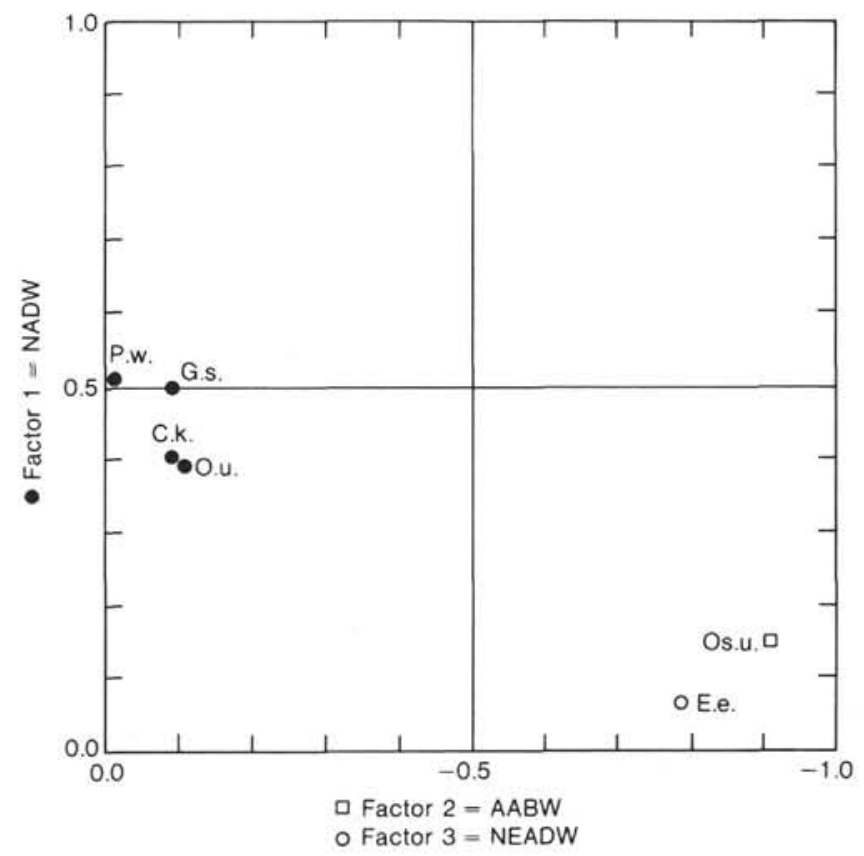

Figure 2. Plot of the principal species contributing to the varimax factors (data from J. F. Weston, personal communication, 1983). P.w. $=$ Planulina wuellerstorfi, G.s. = Globocassidulina subglobosa, C.k. = Cibicidoides kullenbergi, O.u. = Oridorsalis umbonatus, Os.u. = Osangularia umbonifera, E.e. = Epistomionella exigua .

mixed assemblage plots well within the factor 2 field because its factor 2 score is -0.88 . This shows that some caution must be exercised in the interpretation of factor scores. Nevertheless, from an ecological point of view, the $\mathrm{AABW}$ is quite distinct from both NADW and NEADW.

\section{INTERPRETATION OF NEOGENE ASSEMBLAGES}

Previous work by Schnitker $(1974,1976,1979,1980$, 1982 ) and Streeter and Shackleton (1979) has demonstrated the value of benthic foraminiferal assemblages in the interpretation of Quaternary bottom-water masses in the North Atlantic. Murray (1984) has already used the Recent data base of Weston to interpret the Neogene of Sites 552 to 555 , and Weston has interpreted Site 119 (Weston and Murray, 1984). The same procedure is used here. The fossil foraminiferal assemblages are compared with the Recent Q-mode varimax factors and expressed in terms of those factors. It should be understood that the correlation of fossil assemblages with modern water masses does not indicate that the past water masses were identical with those of today, but only that they may have been similar; hence my use of the terms "NADW", "NEADW", and "AABW" with qualifying quotation marks to distinguish them from the true modern water masses.

\section{Hole 609B}

The planktonic:benthic ratio is normally $98: 2$ or $99: 1$ in oceanic sediments. Values $<98$ for the planktonic component indicate dissolution of planktonic tests, and this is the case for the upper Miocene and most lower Plio- 


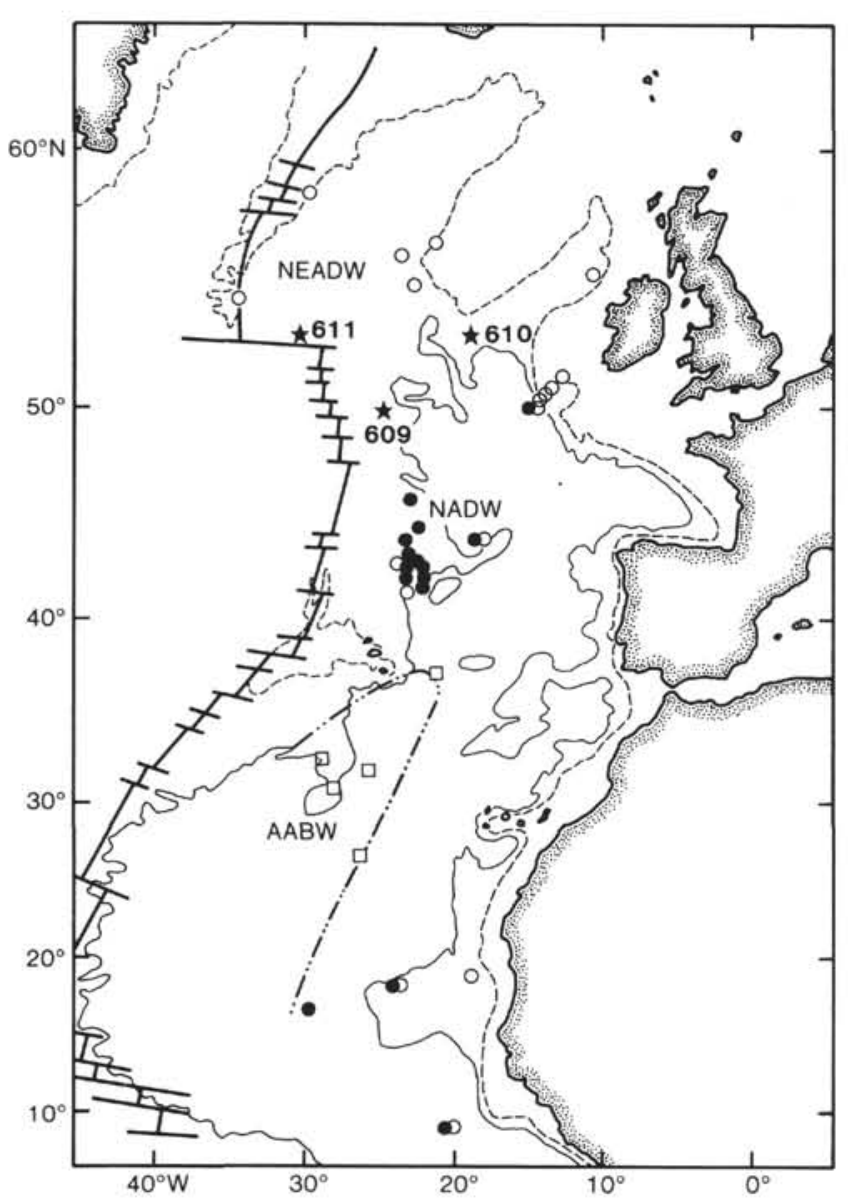

Figure 3. Distribution of the three varimax factors in Recent assemblages from the northeast Atlantic: open circle $=$ factor 3 , NEADW; solid circle = factor 1 , NADW; $\square=$ factor 2 , AABW (data from J. F. Weston, personal communication, 1983). Dashed contour $=2000-\mathrm{m}$ isobath; solid contour $=4000-\mathrm{m}$ isobath; dashed-dotted contour = boundary of AABW. Leg 94 sites shown for comparison with Figure 1. cene samples (609B-36, CC to 609B-30,CC). The diversity index for the benthic assemblage is moderately high throughout. With the possible exception of Sample 609B$36, \mathrm{CC}$, none of the samples has suffered serious dissolution, and even this one may not have been much affected. The composition of the assemblages is given in Table 4.

The relative abundances of those species indicative of water masses are plotted on Figure 8. Osangularia umbonifera had abundance peaks in the late Miocene and early Pliocene, which must represent an "AABW" influence, but thereafter this species was rare or absent. Epistominella exigua had particularly strong peaks in the late Pliocene, just before the onset of glacial conditions, and in the Pleistocene. The two most abundant "NADW" species are Globocassidulina subglobosa and Oridorsalis umbonatus.

The results of the varimax factor analysis (Table 4, Figs. 8-10) show a distinctive pattern of factor distribution. In the late Miocene and early Pliocene there was alternation in dominance between factors 1 and 2, indicating "NADW" and "AABW." Osangularia umbonifera declined to low abundance in the late Pliocene and disappeared completely soon after the onset of glacial conditions. Throughout the late Pliocene and Pleistocene there was alternation in dominance between factors 1 and 3, representing "NADW" and "NEADW." The only sample that cannot be interpreted in terms of factors is $609 \mathrm{~B}-5, \mathrm{CC}$, which has low scores on all factors. Except for Samples 609B-5,CC and 609-15,CC, all the samples have $>50 \%$ explained loadings on the varimax factors, which means that they are fairly similar to the modern assemblages.

\section{Site 610}

The planktonic:benthic ratio is high throughout the sediment section at this site, so little or no dissolution has taken place. Benthic diversity is moderate to high ( $\alpha$ of 11 to 21). The compositions of the assemblages are

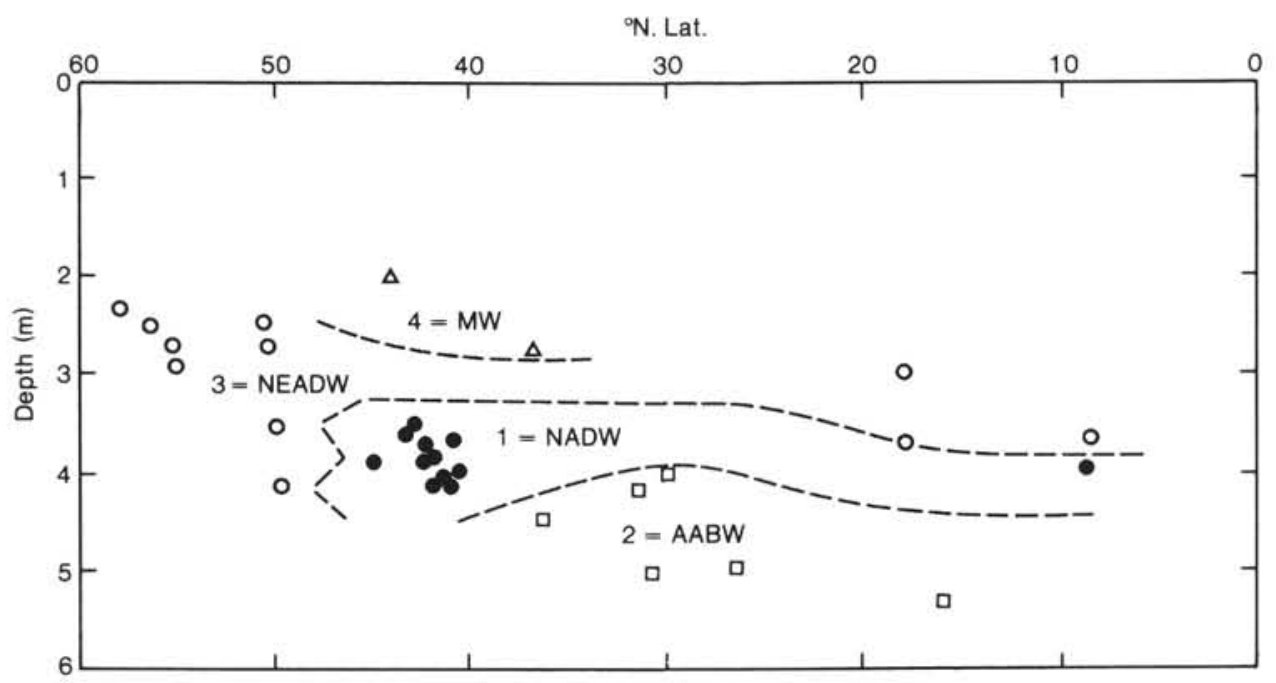

Figure 4. A latitude-vs.-depth graph of the Recent-assemblage varimax factors for the northeast Atlantic (data from J. F. Weston, personal communication, 1983). MW = Mediterranean Water. 


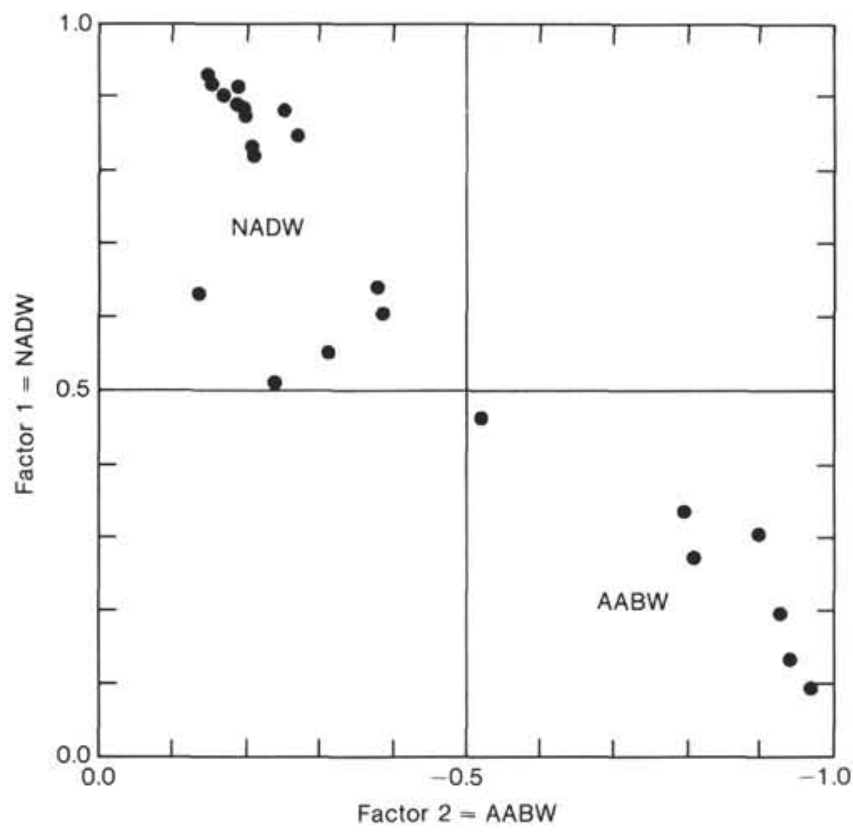

Figure 5. Plot of factors 1 and 2 for the Recent assemblages (data from J. F. Weston, personal communication, 1983).

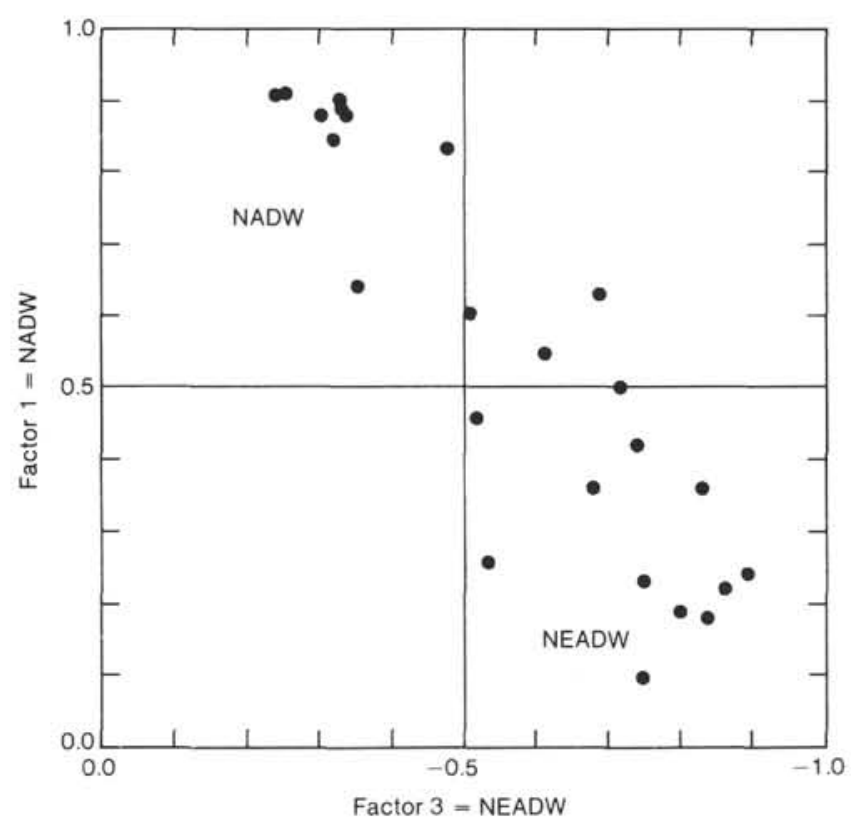

Figure 6. Plot of factors 1 and 3 for the Recent assemblages (data from J. F. Weston, personal communication, 1983).

given in Table 5 . The relative abundances of species indicative of "NADW" and "NEADW" are plotted in Figure 11. Osangularia umbonifera has not been recorded, so no "AABW" influence operated from middle Miocene times onward. Epistominella exigua (representing "NEADW") was abundant in Zones NN5 and NN7 of the middle Miocene and throughout much of the late Miocene. It had intermittent peaks of abundance in the late Pliocene and Quaternary. Oridorsalis umbonatus is the principal component of the "NADW" group. From the late Miocene Zone NN11 to the early Pliocene Zone

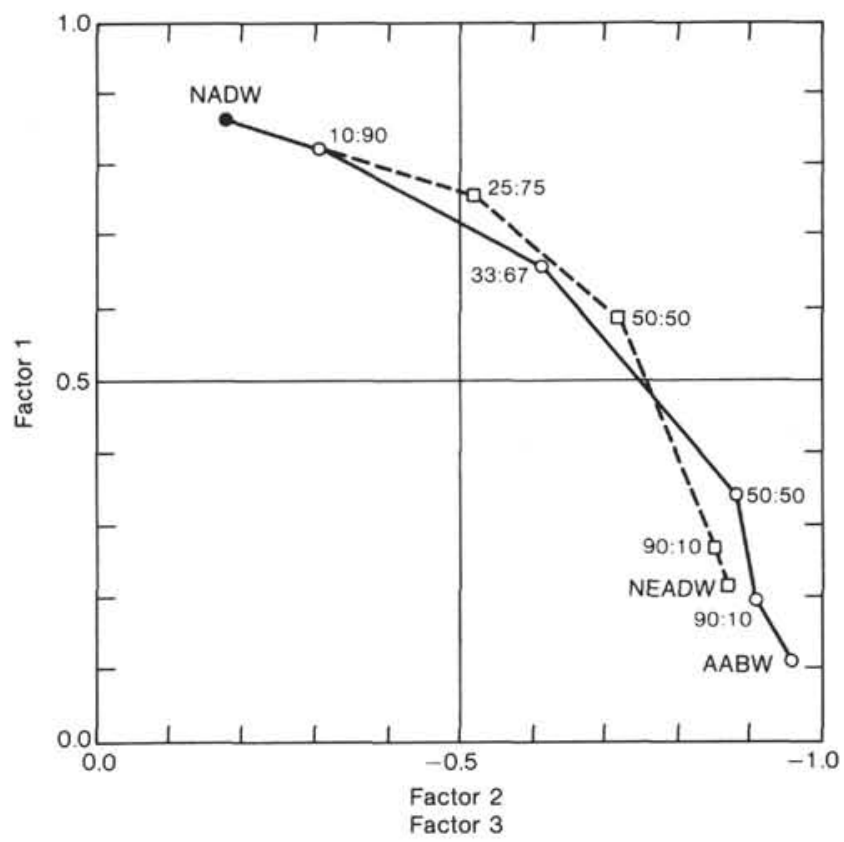

Figure 7. Modeled assemblages. Ratios are for NADW:AABW (open circles); NADW:NEADW ( $\square$ ).

NN15, and also in the Quaternary (Sample 610-5,CC), none of these indicator species was common, whereas non-indicator species of unilocular (Fissurina, Lagena, Oolina) and uniserial (Nodosaria, Stilostomella) genera were quite common.

The varimax factor analysis shows that in only six samples is more than $50 \%$ loading of the factors explained. Thus, most of the samples cannot reliably be assigned to water masses. The best results are for Hole 610 Samples 15,CC, 13,CC, 12,CC, and 1,CC (all "NEADW") and Samples 610-14,CC and 610E-2,CC (both "NADW") (Fig. 12).

\section{Hole 611C}

Slight to moderate dissolution of planktonic tests is evident in the upper Miocene, the lowermost lower Pliocene, and much of the upper Pliocene. The diversity values for the benthic assemblages are generally moderate to high, however, suggesting little if any dissolution, except perhaps in Sample 611C-15,CC ( $\alpha$ of 7). The composition of the assemblages is given in Table 6 .

The relative abundances of species indicative of water masses are plotted on Figure 13. The varimax factor analysis (Table 6, Figs. 13-15) shows that, excepting Samples $611 \mathrm{C}-35, \mathrm{CC}$ to $611 \mathrm{C}-22, \mathrm{CC}$, less than $50 \%$ of the loading on the factors is explained. Therefore, for the upper Miocene, Sample $611 \mathrm{C}-47, \mathrm{CC}$ plots close to the "NEADW" field (Fig. 15), samples 611C-44,CC and $611 \mathrm{C}-43, \mathrm{CC}$ are not clearly related to any of the water masses, and 611C-39,CC is of the "NADW" type. Sample $611 \mathrm{C}-35, \mathrm{CC}$ is a "NADW"-"NEADW" mix, as is lower Pliocene Sample 611C-32,CC. In 611C-30,CC, Osangularia umbonifera forms nearly $10 \%$ of the assemblage, and the water mass is "NADW" with some admixed "AABW". This influence is seen in a small way in Sample 611C-22,CC (with "NADW") and Sample 
Table 4. Census data for Hole 609B.

\begin{tabular}{|c|c|c|c|c|c|c|c|c|c|c|c|c|c|c|c|c|c|c|c|}
\hline & \multicolumn{19}{|c|}{ Core-catcher samples } \\
\hline & 1 & 3 & 5 & 12 & 15 & 17 & 19 & 20 & 21 & 23 & 25 & 26 & 27 & 28 & 30 & 32 & 33 & 34 & 36 \\
\hline Astrononion guadelupae & - & - & - & 5 & 4 & 8 & - & 12 & 15 & 12 & 15 & 1 & - & 11 & 15 & 12 & 2 & 4 & 2 \\
\hline Bolivina cf. B. thalmanni & - & - & - & - & - & - & - & - & - & - & - & - & - & - & - & - & - & - & 1 \\
\hline Bulimina alazanensis & - & - & - & - & - & - & - & - & - & - & - & - & - & - & - & - & - & - & - \\
\hline Bulimina striata & - & - & - & - & - & - & - & - & - & - & - & - & - & - & - & - & - & - & - \\
\hline Cassidulina obtusa & 1 & 2 & 2 & 1 & 9 & 5 & 6 & - & - & 1 & 2 & 3 & - & 3 & 5 & 1 & - & 5 & - \\
\hline Cassidulina teretis & 1 & - & - & - & - & - & - & - & - & - & - & - & - & - & - & - & - & - & - \\
\hline Cassidulina sp. & - & - & - & - & - & - & - & 2 & - & - & - & - & 3 & - & 3 & - & - & - & - \\
\hline Cibicidoides bradyi & - & - & - & 9 & 1 & - & - & - & - & - & - & - & - & - & - & - & - & - & 1 \\
\hline Cibicidoides kullenbergi & - & - & - & - & - & - & - & - & - & - & 1 & - & 4 & 3 & - & - & 1 & - & 3 \\
\hline Cibicidoides spp. & 1 & - & - & 2 & - & 6 & 4 & - & - & 2 & - & 5 & - & 5 & 5 & 5 & 1 & 8 & 2 \\
\hline Eggerella bradyi & 13 & 5 & 5 & 4 & 9 & 9 & 13 & 12 & 8 & 12 & 7 & 8 & 6 & 1 & 8 & 7 & 2 & 11 & 12 \\
\hline Ehrenbergina serrata & - & - & - & - & - & - & - & - & - & - & - & - & 9 & 5 & 10 & 10 & 11 & 4 & - \\
\hline Ehrenbergina trigona & - & - & - & - & 1 & - & - & - & - & - & - & - & $\cdots$ & - & - & - & - & - & - \\
\hline Epistominella exigua & 28 & 89 & 2 & 7 & 18 & 38 & 63 & 36 & 32 & 37 & 14 & 18 & 1 & 4 & 8 & 8 & 5 & 30 & 17 \\
\hline Epistominella levicula & 1 & - & 8 & - & 29 & 10 & 4 & - & 7 & - & - & - & - & - & 3 & - & - & - & - \\
\hline Eponides polius & 2 & - & - & 8 & - & - & - & 4 & 3 & 7 & - & - & - & 1 & - & - & - & 1 & 2 \\
\hline Eponides tumidulus & 1 & 4 & 7 & 4 & 2 & - & 2 & 7 & - & - & 4 & - & - & - & - & - & $\overline{-}$ & 3 & - \\
\hline Fissurina, Lagena, Oolina & 8 & 24 & 10 & 11 & 8 & 11 & 8 & 5 & 10 & 10 & 9 & 17 & 27 & 24 & 18 & 13 & 7 & 19 & 11 \\
\hline Francesita advena & - & 3 & 5 & - & $\overline{-}$ & - & 1 & 1 & - & - & - & - & - & - & - & - & - & 8 & $\overline{0}$ \\
\hline Globocassidulina subglobosa & 1 & 19 & - & 24 & 7 & 5 & 11 & 27 & 32 & 18 & 27 & 22 & 24 & 20 & 20 & 18 & 20 & 18 & 20 \\
\hline Globulina, Guttulina & - & - & - & 5 & 1 & - & - & 7 & 3 & - & - & - & - & 3 & 2 & 2 & 2 & - & - \\
\hline Gyroidinoides spp. & 6 & 9 & 14 & 9 & 8 & 15 & 13 & 12 & 3 & 7 & 11 & 21 & 11 & 15 & 17 & 31 & 7 & 9 & 23 \\
\hline Hoeglundina elegans & - & - & - & - & - & - & - & - & - & - & - & - & - & - & - & - & - & - & $\overline{0}$ \\
\hline Laticarinina pauperata & - & - & - & 2 & - & - & 1 & 2 & 2 & 1 & - & 1 & 1 & - & 3 & - & - & - & 2 \\
\hline Lenticulina sp. & - & 1 & 1 & - & - & - & 1 & - & 1 & 1 & - & 2 & - & 1 & - & - & - & $\overline{-}$ & 1 \\
\hline Melonis barleeanus & 12 & 5 & 14 & 1 & 10 & 10 & 5 & 8 & 5 & 12 & 2 & 13 & 15 & 13 & 15 & 15 & 4 & 7 & 16 \\
\hline Melonis pacificus & 7 & 3 & - & - & 1 & 4 & 5 & 2 & 3 & 6 & 5 & 6 & 4 & 3 & - & - & - & - & - \\
\hline Melonis pompolioides & - & - & - & - & - & 1 & - & - & - & - & 4 & - & - & 1 & 1 & - & 1 & - & - \\
\hline Nodosaria, Stilostome $! ! \lambda$ & - & 1 & $\overline{-}$ & 3 & 2 & 2 & - & 2 & 6 & 2 & 2 & 5 & 12 & 7 & - & 5 & - & 2 & 3 \\
\hline Oridorsalis umbonatus & 30 & 19 & 20 & 25 & 15 & 17 & 25 & 5 & 10 & 24 & 15 & 24 & 7 & 8 & 22 & 16 & 25 & 16 & 7 \\
\hline Osangularia umbonifera & - & 1 & - & - & - & 4 & 3 & 11 & 5 & 6 & 7 & 12 & 21 & 41 & 17 & 35 & 10 & 42 & 54 \\
\hline Planulina wuellerstor $f i$ & 3 & 26 & 2 & 9 & 5 & 4 & 2 & - & 2 & - & 7 & 4 & 5 & 7 & 12 & 15 & 6 & 4 & - \\
\hline Pleurostomella & - & - & - & - & - & 1 & - & - & - & 2 & 1 & 6 & 4 & - & 3 & - & - & 2 & - \\
\hline Pullenia bulloides & 1 & - & - & 3 & 5 & 1 & 1 & 2 & - & 2 & - & - & - & - & - & 2 & - & - & $\bar{n}$ \\
\hline Pullenia osloensis & 7 & 3 & 12 & 9 & 14 & 19 & 13 & 13 & 14 & 9 & 9 & 15 & 4 & 8 & 7 & 13 & 9 & 19 & 22 \\
\hline Pullenia spp. & 13 & 23 & 19 & 19 & 33 & 15 & 14 & 17 & 15 & 22 & 15 & 3 & 4 & 5 & 3 & 1 & 2 & 13 & 1 \\
\hline Pyrgo spp. & 13 & 6 & 8 & 26 & 2 & 3 & 1 & 5 & 5 & 6 & 3 & 3 & 6 & 1 & 3 & 6 & 1 & 3 & 1 \\
\hline Quinqueloculina spp. & 1 & 6 & 2 & 11 & 1 & 6 & 3 & 7 & 9 & 3 & 10 & 8 & 8 & 3 & 3 & 3 & 1 & 4 & 1 \\
\hline Sigmoilopsis schlumbergeri & - & 1 & - & - & - & $\overline{3}$ & - & - & - & - & - & $\overline{-}$ & - & - & - & - & - & - & $\overline{-}$ \\
\hline Siphotextularia catenata & 2 & - & 3 & 3 & - & 3 & - & - & - & - & - & 3 & 1 & 1 & 2 & - & 1 & 1 & 2 \\
\hline Sphaeroidina bulloides & 1 & - & - & 1 & 1 & - & - & 2 & - & - & - & - & 4 & 4 & - & 1 & - & 1 & 1 \\
\hline Triloculina frigida & 27 & - & - & - & - & - & - & - & - & - & - & - & - & - & - & - & - & $\overline{-}$ & - \\
\hline Uvigerina compreessa & - & - & - & - & - & - & - & - & - & - & - & - & - & 1 & - & - & - & 2 & - \\
\hline Uvigerina spp. & 62 & - & 4 & 3 & 2 & - & - & 1 & 2 & 2 & - & - & 1 & - & 3 & 9 & 9 & - & - \\
\hline Total & 256 & 269 & 154 & 207 & 199 & 201 & 203 & 210 & 206 & 211 & 180 & 204 & 200 & 203 & 210 & 236 & 131 & 234 & 206 \\
\hline Number of species & 41 & 39 & 30 & 37 & 35 & 37 & 34 & 37 & 33 & 40 & 37 & 41 & 39 & 43 & 37 & 39 & 26 & 44 & 35 \\
\hline$\alpha$ index & 14 & 13 & 12 & 13 & 12 & 13 & 12 & 13 & 16 & 15 & 14 & 15 & 13 & 17 & 13 & 14 & 10 & 16 & 12 \\
\hline Factor 1 positive values & 0.4 & 0.4 & 0.4 & 0.6 & 0.3 & 0.3 & 0.3 & 0.4 & 0.5 & 0.4 & 0.6 & 0.5 & 0.5 & 0.3 & 0.6 & 0.4 & 0.6 & 0.3 & 0.2 \\
\hline Factor 2 negative values & 0.2 & 0.2 & 0.3 & 0.3 & 0.3 & 0.3 & 0.3 & 0.4 & 0.3 & 0.4 & 0.4 & 0.5 & 0.6 & 0.8 & 0.5 & 0.7 & 0.5 & 0.8 & 0.8 \\
\hline Factor 3 negative values & 0.6 & 0.8 & 0.3 & 4.2 & 0.5 & 0.7 & 0.8 & 0.5 & 0.5 & 0.6 & 0.3 & 0.4 & 0.1 & 0.1 & 0.2 & 0.2 & 0.1 & 0.4 & 0.2 \\
\hline Explained loadings (\%) & 56 & 83 & 31 & 5s & 44 & 75 & 81 & 71 & 67 & 71 & 71 & 74 & 61 & 77 & 70 & 71 & 70 & 90 & 84 \\
\hline
\end{tabular}

Note: Dash indicates not present.

611C-21,CC. The late Pliocene assemblages are ill-defined ( $<50 \%$ loading explained). Samples $611 \mathrm{C}-18, \mathrm{CC}$ and $611 \mathrm{C}-16, \mathrm{CC}$ cannot be assigned to any water mass; sample $611 \mathrm{C}-15, \mathrm{CC}$ is of the "NEADW" type, but may have undergone some dissolution of benthic tests (low diversity). In the glacially influenced succession, the assemblages are close to "NEADW" $(611 \mathrm{C}-13, \mathrm{CC})$ or "NADW" $(611 \mathrm{C}-9, \mathrm{CC})$, and the topmost sample is of the "NEADW" type.

\section{General Features of the Faunas}

The age range of the samples studied is from middle Miocene to Pleistocene.

A few forms are restricted to the lower part, for example, Spiroplectammina spectabilis and Siphonina tenuicarinata, found only in Zone NN5 in Samples 610$17, \mathrm{CC}$ and $610-18, \mathrm{CC}$.

A second group of species, which includes Bulimina alazanesis, Ehrenbergina serrata, and E. trigona, is essentially confined to the preglacial succession (Fig. 16). A similar pattern was observed at Sites 552 to 555 (Murray, 1984). Laticarinina pauperata, which showed the same pattern at Sites 552 to 555 , here extends into the Pleistocene.

Two other species are confined to the Pleistocene (Cassidulina teretis and Triloculina frigida), and again the distribution is essentially the same as that at Sites $\mathbf{5 5 2}$ to 555 .

In the northeast Atlantic, the modern distributions are as follows: Bulimina alazanensis occurs along the continental slope (Fig. 17). Ehrenbergina serrata and E. trigona are rare and present in abyssal areas overlain by AABW (south of the Azores) or NADW (King's Trough). Laticarinina pauperata is present on the mid-ocean ridge and flanks of King's Trough. These three species are more widely distributed in the deep sea at low latitudes. Triloculina frigida (first described from the Arctic Ocean) and Cassidulina teretis are present in northern areas and are indicative of cold, northern-derived waters.

\section{Relationship to Lithology}

Each of the three main sites has the same general lithologic characteristics: an upper unit showing alternation of calcareous oozes and terrigenous oozes, correspond- 


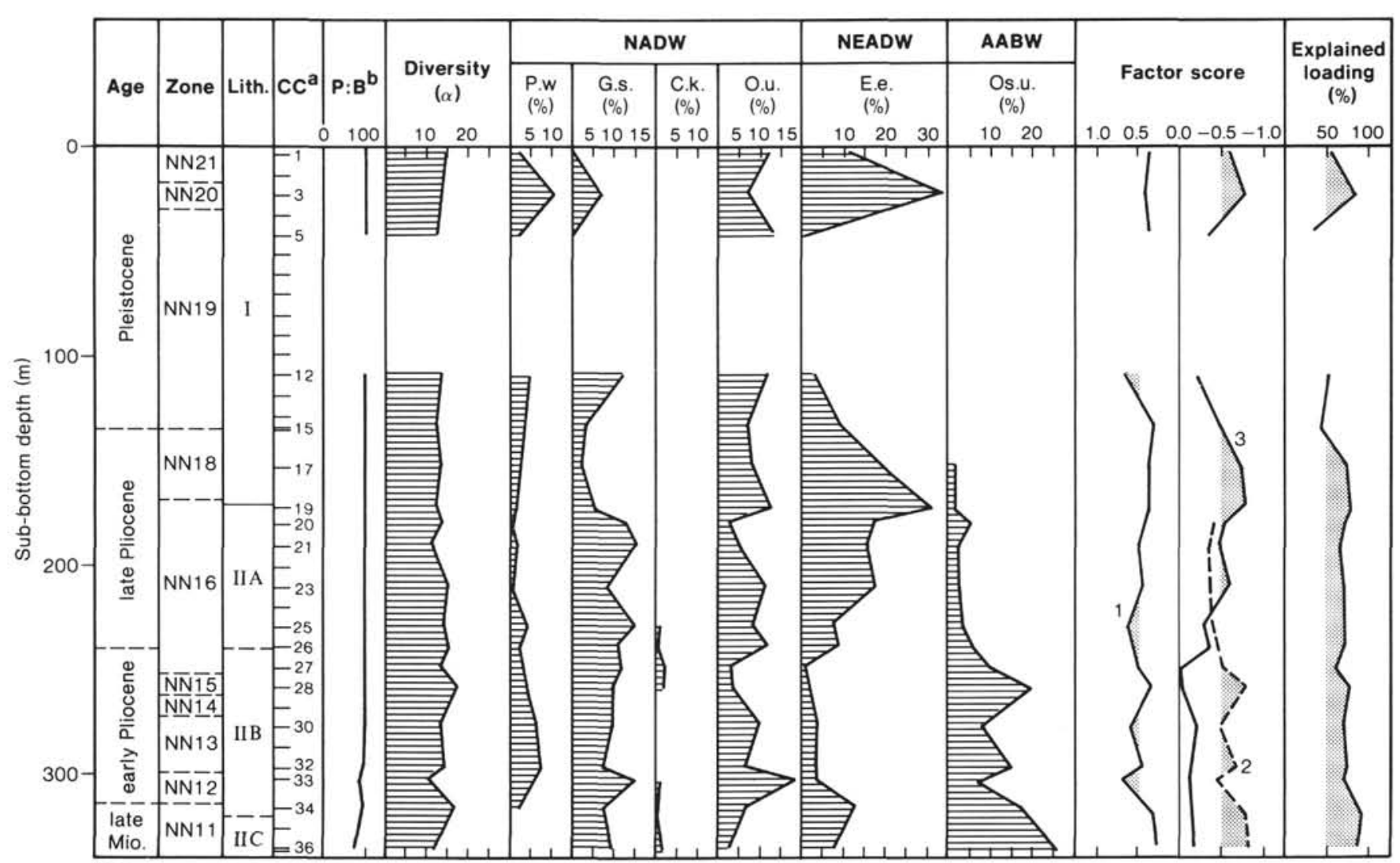

${ }^{\mathrm{a}} \mathrm{CC}=$ core-catcher sample

${ }^{b} \mathrm{P}: \mathrm{B}=$ planktonic : benthic ratio

Figure 8. Summary of significant paleontological features, Hole 609B. Species abbreviations as for Figure 2. Factor scores $>0.5$ or $>-0.5$ are stippled.

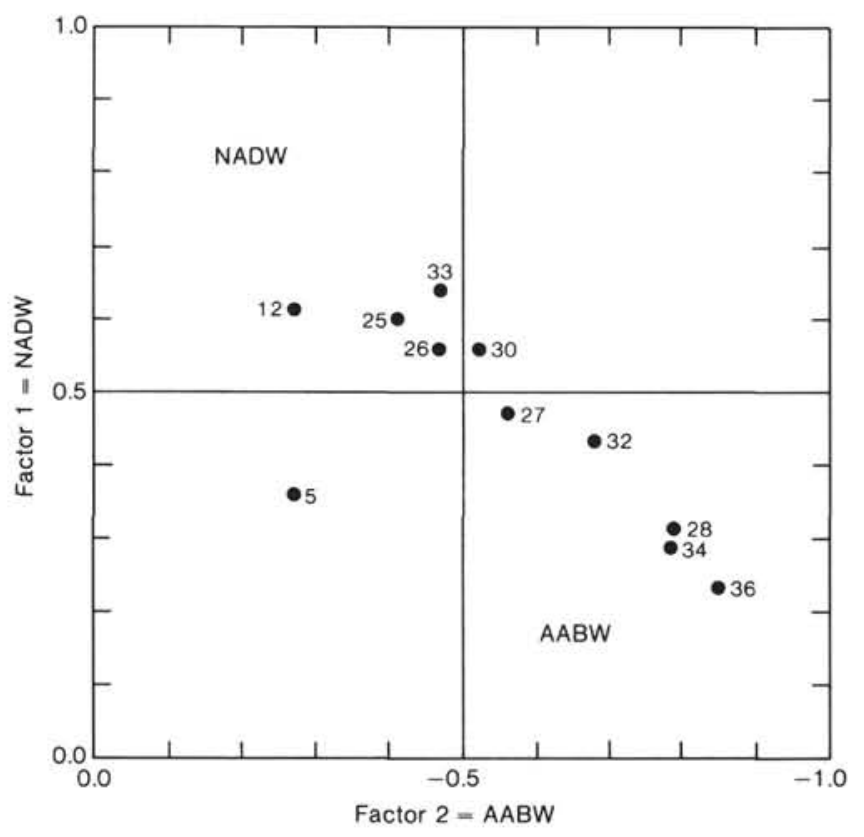

Figure 9. Hole 609B assemblages expressed in terms of varimax factors 1 and 2 of the Recent assemblages. Numbers denote core-catcher samples.

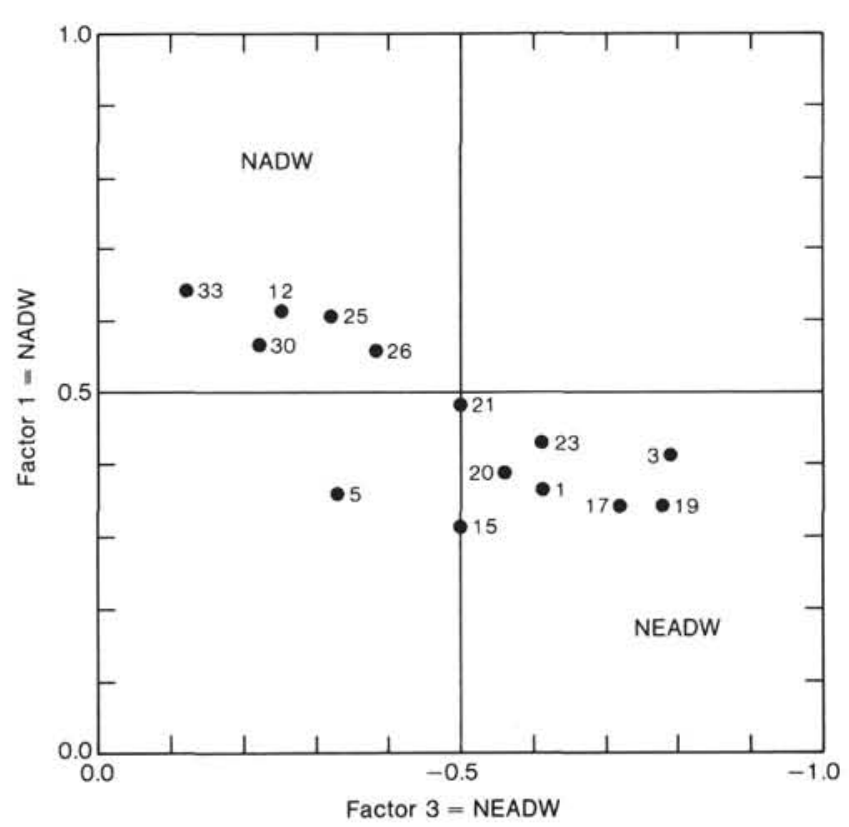

Figure 10. Hole 609B assemblages expressed in terms of varimax factors 1 and 3 of the Recent assemblages. Numbers denote corecatcher samples. 
Table 5. Census data for Holes 610, 610A, 610E.

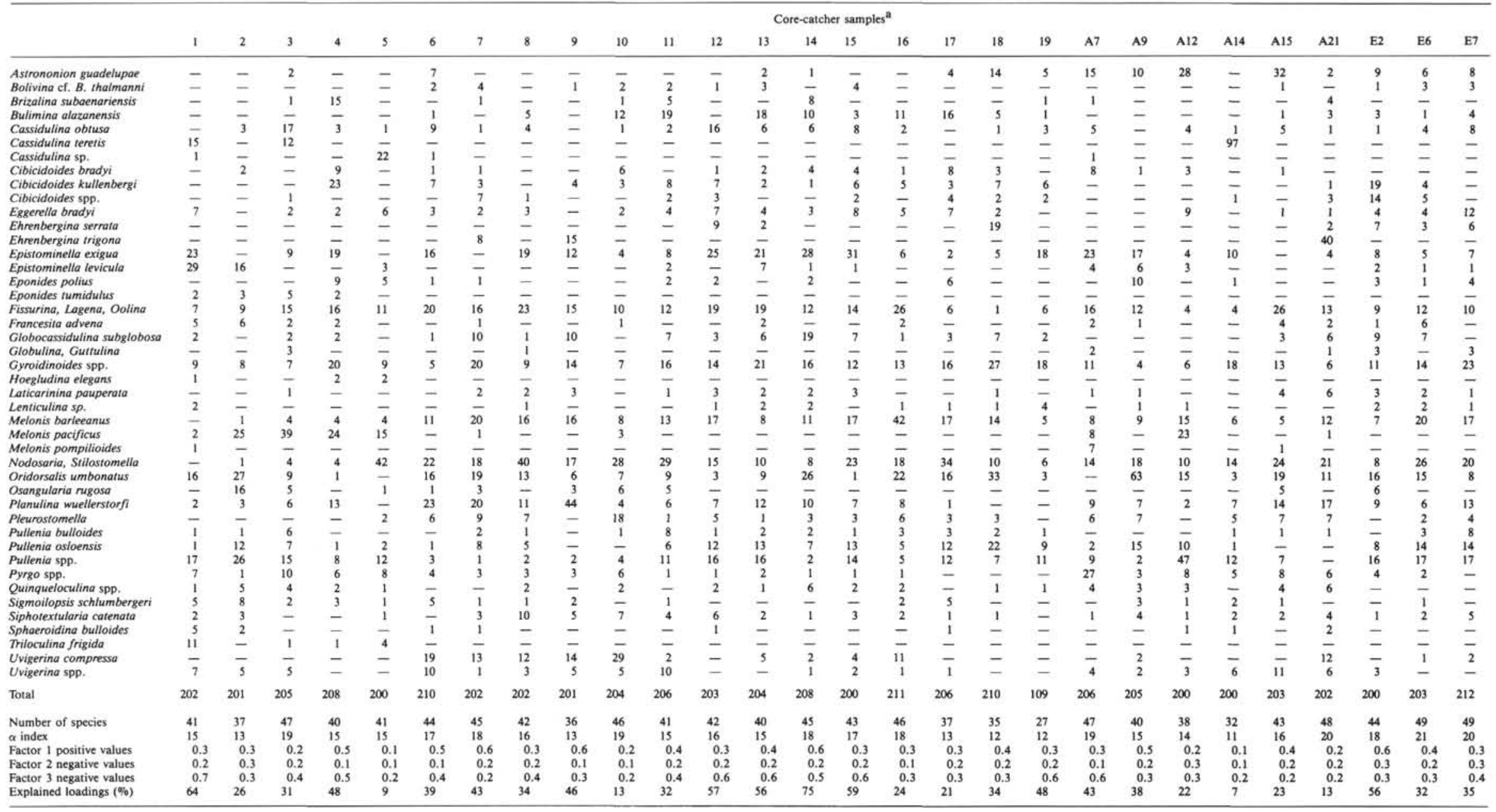

Note: Dash indicates not present.
$\mathrm{a}$ A denotes Hole $610 \mathrm{~A} ; \mathrm{E}$ denotes Hole $610 \mathrm{E}$. 


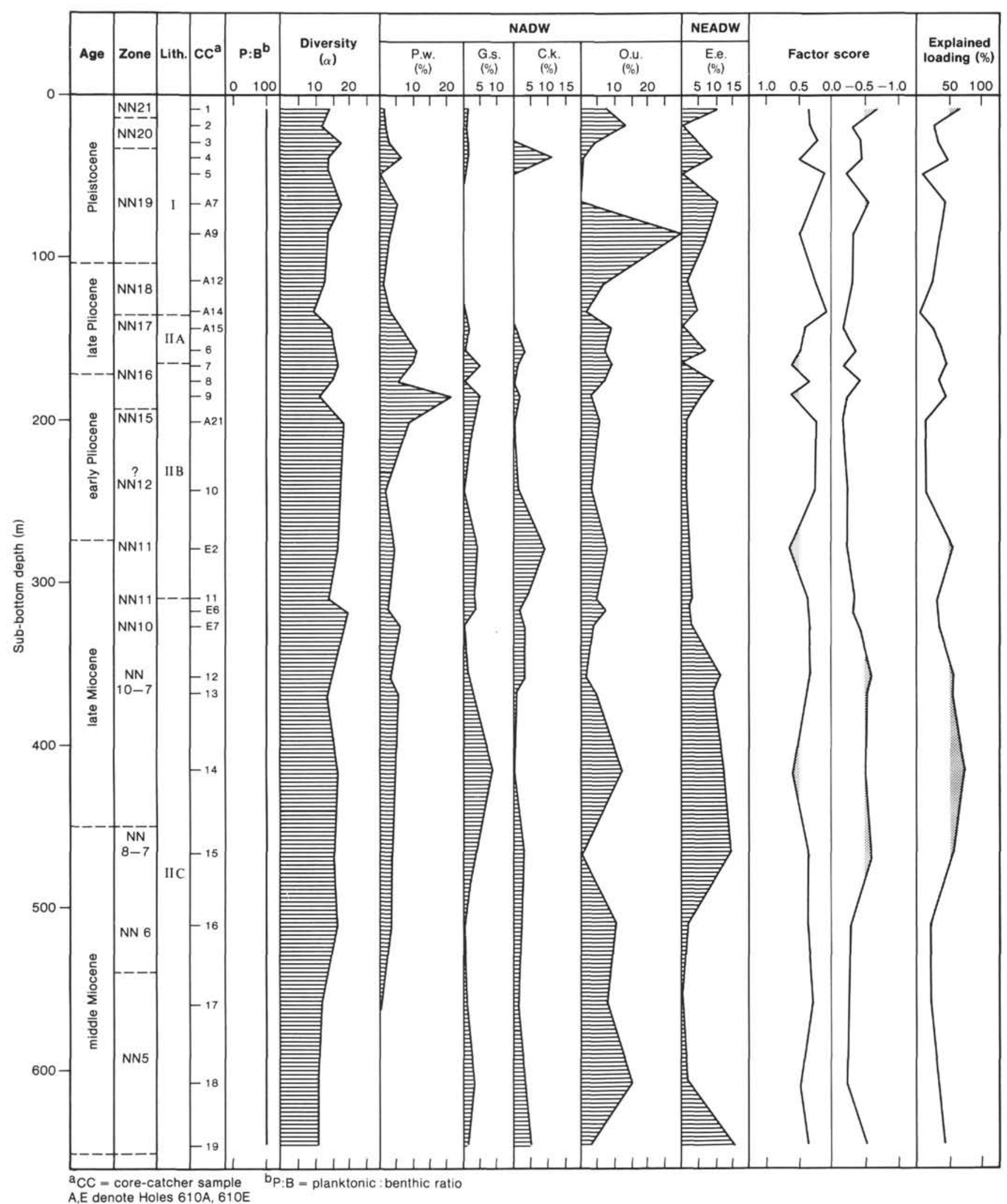

Figure 11. Summary of significant paleontological features, Site 610. Species abbreviations as for Figure 2. Factor scores $>0.5$ or $>-0.5$ are stippled. 


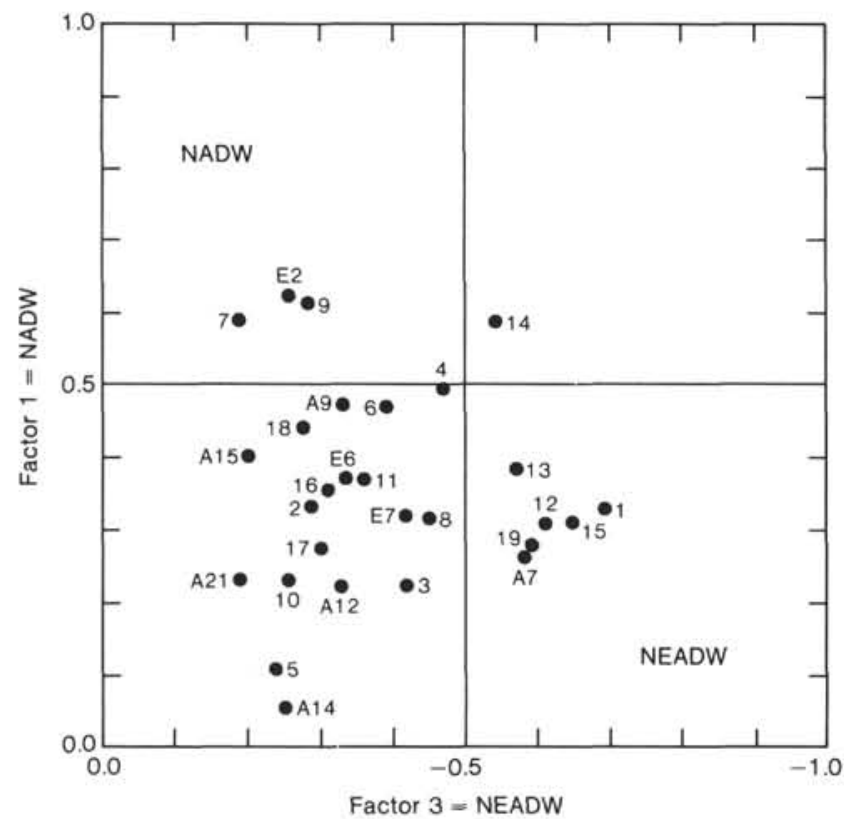

Figure 12. Site 610 assemblages expressed in terms of varimax factors 1 and 3 of the Recent assemblages. Numbers denote core-catcher samples. $(\mathrm{A}=$ Hole $610 \mathrm{~A} ; \mathrm{E}=$ Hole $610 \mathrm{E})$.

ing to interglacials and glacials, respectively, and a lower unit of nannofossil ooze or chalk corresponding to the preglacial Pliocene and Miocene. Site 610 is situated on the Feni Drift; Hole 611 is in a wave-trough on the Gardar Drift. It seems likely that contourite deposition ceased with the commencement of the late Pliocene glacial sedimentation.

There is no obvious lithologic control on the distribution of the benthic foraminifers, but as both sediments and the foraminifers are ultimately controlled by the distribution of water masses and bottom currents there is an indirect correlation between them.

\section{DISCUSSION}

By themselves, these three sites are not enough to allow evaluation in detail of the changes in Neogene bottom-water distribution. They do, however, give an indication of some of the patterns of change that have taken place.

The record at Hole 609B is particularly good, perhaps because it was not the site of drift deposition. Upper Miocene to upper Pliocene assemblages have $>70 \%$ explained loadings on the varimax factors, and are therefore very similar to the modern assemblages (Fig. 8). At Site 610 only the upper Miocene and at Site 611 only the upper Miocene to lower Pliocene assemblages have $>50 \%$ explained loadings on the varimax factors. Many of the assemblages are therefore rather different from the modern ones.

The results from the three main sites have been summarized in Table 7. This shows that "AABW" occupied Site 609B from the late Miocene to the early Pliocene, with only brief intervals of "NADW." "AABW" was not present at all during this time at Site 610 (possibly it was too shallow), and it made discontinuous appearances at Site 611 during the early Pliocene. This is shown diagrammatically in Figure 18. The northern limit of "AABW" has shown marked changes in position since the late Miocene. Then it lay between Sites 609 and 611 (Fig. 19). It reached its northernmost extent during the early Pliocene (Zones NN12, NN13, NN15), when it extended north of Site 611. By the latest early Pliocene (NN16, base), it had reverted to the late Miocene position between Sites 611 and 609. In the late Pliocene it lay to the south of Site 609. From the few Pleistocene samples studied, this appears also to have been the case during the Pleistocene. As might be expected, Site 608 had O. umbonifera, and therefore an "AABW" influence, from the middle Miocene (NN9) until the earliest Pleistocene (NN19) (see Site 608 report). The northern limit of modern AABW influence lies to the south of the Azores, and it is probable that the AABW has had a continuous presence there throughout the middle Miocene to Recent.

At Sites 405,406 , and 552 to 555 , to the southwest of Rockall Plateau (depth 1666-2958 m), no "AABW" has been detected in the Neogene record, but it has been recorded from the middle and late Miocene, Pliocene, and briefly in the Pleistocene at Site 119 (depth $4447 \mathrm{~m}$ ) in the Bay of Biscay (Weston and Murray, 1984).

"NADW" was present from the late Miocene until the late Pliocene. It was sometimes mixed with "AABW" and occasionally with "NEADW" (as in Zones NN11NN12, Site 611). "NEADW" was also present in the middle to late Miocene at Site 610 (Figure 11). "NEADW" did not become widespread, however, until the late Pliocene (NN16), and all three sites are at present overlain by "NEADW". These results confirm the conclusion that this water mass, which has a Labrador Sea Water component, was not important before the Pliocene (Weston and Murray, 1984).

These results can be placed in the broader context of well-documented events from other oceans. The first of these events was the development of the maximum extent of ice on Antarctica (see Fig. 18). The buildup of ice on Antarctica was studied by Hayes and Frakes (1975) from the distribution of ice-rafted sediments. These appeared by the late Oligocene at $77^{\circ} \mathrm{S}$ latitude and progressively later at sites at lower latitudes. Shackleton and Kennett (1975b) pointed out that, although glaciers had reached sea level from the early Oligocene, the rapid and major buildup of continental ice took place in the early middle Miocene and led to the formation of the East Antarctic ice cap. The evidence for this came from DSDP Sites 277, 279 and 280, south of New Zealand and Australia. Shackleton and Kennett (1975a) interpreted oxygen-isotope evidence from Site 284 benthic foraminifers as indicating that in the latest Miocene the Antarctic ice cap was $50 \%$ larger than at present and that in the Pliocene it shrank. Other workers believe that glacial conditions were present throughout the Cenozoic and that variations in global ice volume may have been overestimated (Matthews and Poore, 1980; Poore and Matthews, 1984; Keigwin and Keller, 1984).

The results presented here show that "AABW" penetrated far north in the late Miocene (Hole 609B), al- 
Table 6. Census data for Hole 611C.

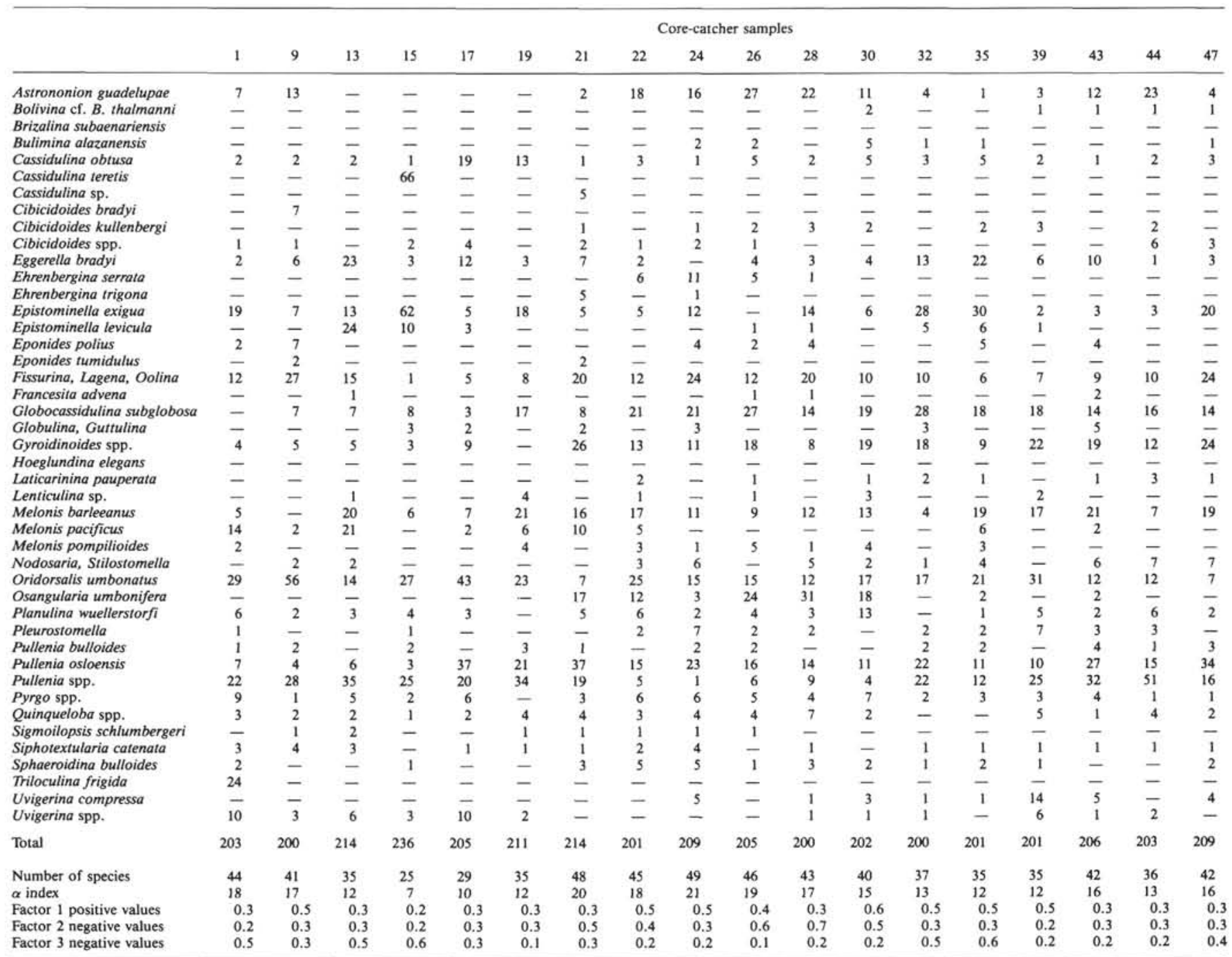

Note: Dash indicates not present.

though it reached its maximum extent in the early Pliocene (Hole 611C).

The second major event was the Messinian "salinity crisis" (Hsü et al., 1973), during which the Mediterranean was isolated from the Atlantic Ocean. This should have affected the production of "NADW". Blanc and Duplessy (1982) used carbon isotopic evidence to infer that during this period the supply of young northern water to the northeast Atlantic ceased. The deep waters had a longer residence time and were derived from "AABW" and other waters having a southerly source.

The evidence from Sites 609-611 is not very satisfactory for this period. No samples were available from Hole 609B. At Site 610 the biostratigraphic control is poor, and the assemblages from Zone NN12 are not definitive of any water mass. At Hole $611 \mathrm{C}$ they are of mixed "NADW"-"NEADW" type, that is, not clearly defined.

The third event was the resumption of formation of "NADW" at the beginning of the Pliocene (Blanc and Duplessy, 1982). Evidence for this is seen in Sample 609B33, CC (although there has been some dissolution). The
Labrador Current was also initiated at this time (Berggren and Schnitker, 1983), and this played a part in the formation of NEADW.

The fourth and final major event was the buildup of continental ice in the Northern Hemisphere at $\sim 3.2 \mathrm{Ma}$ (Shackleton and Opdyke, 1977) or at $2.4 \mathrm{Ma}$ (Shackleton et al., 1984). Associated with this cooling of the northern waters, true modern NADW must have been formed (Schnitker, 1980). Its arrival in the Antarctic caused cooling of Antarctic water and increased the production and rate of flow of AABW into the southwest Atlantic (Ledbetter et al., 1978).

The zone of contact between the AABW and NADW is a "wedging" teleconnection, that is, it is nearly horizontal or slightly inclined, up to several hundred meters in thickness, and extends over several thousand kilometers (Johnson, 1982). It follows that a change in the flow rate of one or another of the water masses may lead to a large lateral displacement of the contact zone. In the northeast Atlantic, the Azores Ridge forms a topographic barrier to AABW moving up from the south. For the 


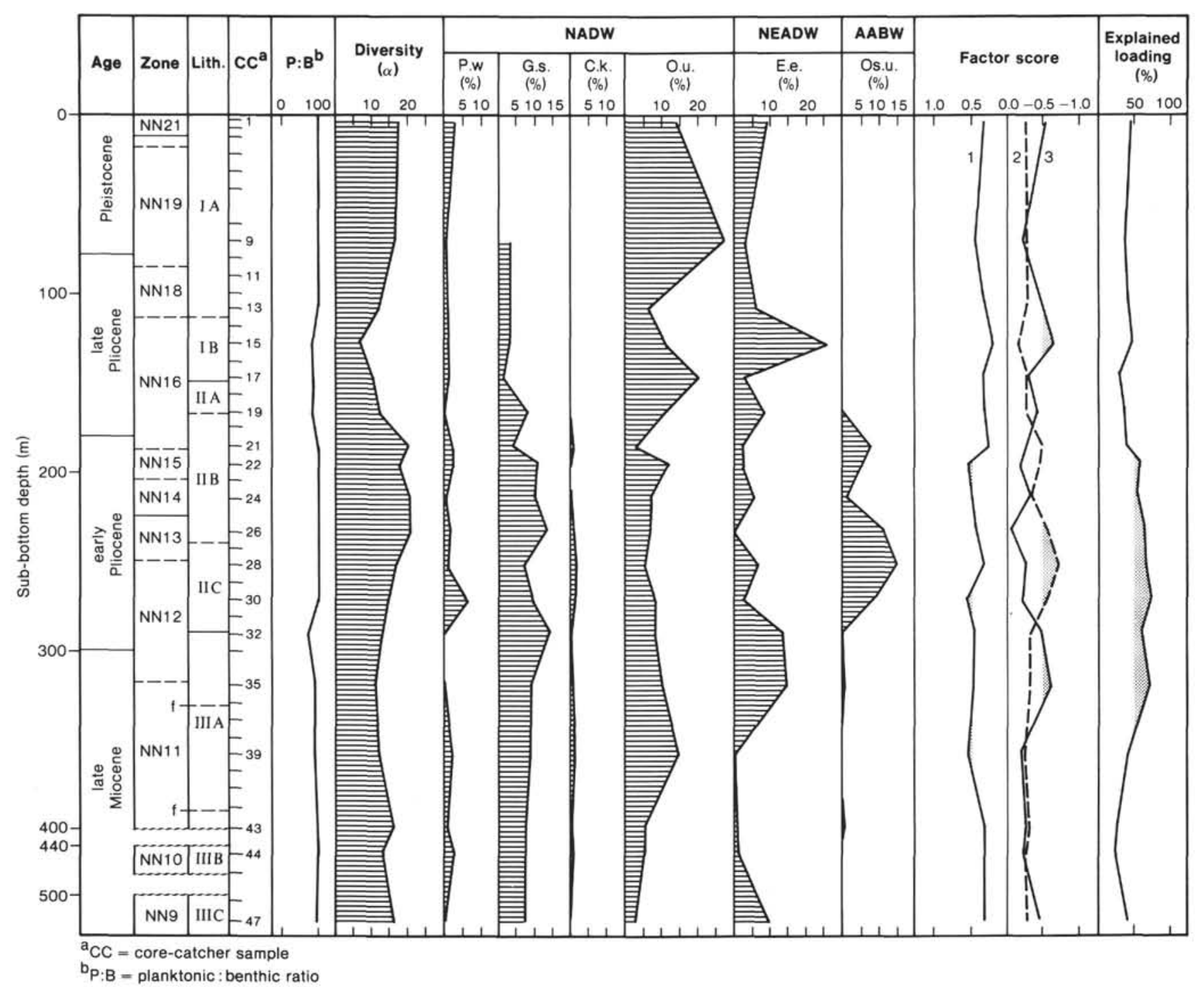

Figure 13. Summary of significant paleontological features, Hole 611C. Species abbreviations as for Figure 2. Factor scores $>0.5$ or $>-0.5$ are stippled; $f=$ fault.

distribution to extend to the north of the ridge, the thickness of the AABW layer must have increased sufficiently to pass over the sill. This appears to have been the case in the northeast Atlantic during the late Miocene to late Pliocene. The intensity of input of "AABW" may have increased to a peak in the early Pliocene (NN13), was perhaps reduced in NN14, and may have increased again in NN15. With the onset of continental ice buildup, "NADW" production may have increased, and this may account for the displacement of the "AABW""NADW" contact to the south (Figs. 18, 19).

From the data presented here, it can be concluded that the benthic foraminiferal assemblages of the northeast Atlantic record relative changes in the distribution of bottom waters.

\section{SUMMARY}

The late Neogene benthic foraminiferal assemblages, like their modern counterparts, seem to be linked to the distribution of bottom-water masses. Because the late Neogene fauna is modern in its species composition, it is possible to interpret the fossil record in terms of the modern data (using varimax factor analysis). The principal modern water masses are AABW, NADW, and NEADW. The latter two are variants of one another, and they are quite distinct from AABW. During the early Pliocene, "AABW" extended farthest north, but in the late Pliocene, increased production of "NADW" caused the "AABW"/ "NADW" contact to be displaced to the south, and it now lies to the south of the Azores. I conclude that these benthic foraminiferal assemblages give a record of relative changes in the distribution of bottom-water masses in the northeast Atlantic.

\section{ACKNOWLEDGMENTS}

Dr. P. Weaver (Institute of Oceanographic Sciences) kindly supplied the unprocessed core-catcher samples. Dr. J. F. Weston (Stratigraphic Services International) generously made available data on the 


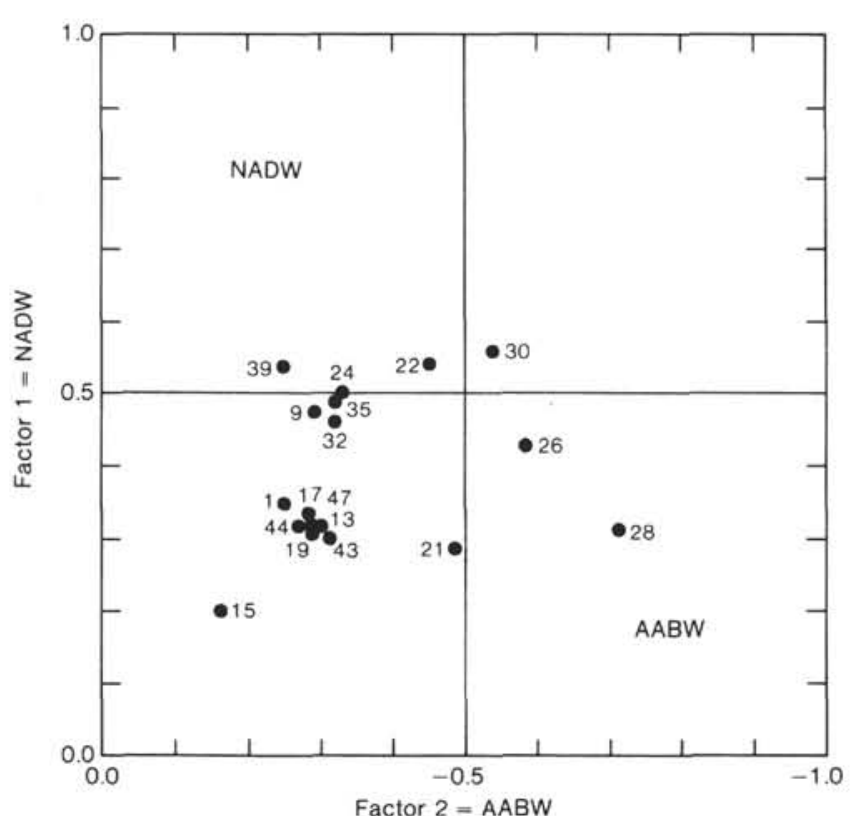

Figure 14. Hole $611 \mathrm{C}$ assemblages expressed in terms of varimax factors 1 and 2 of the Recent assemblages. Numbers denote corecatcher samples.

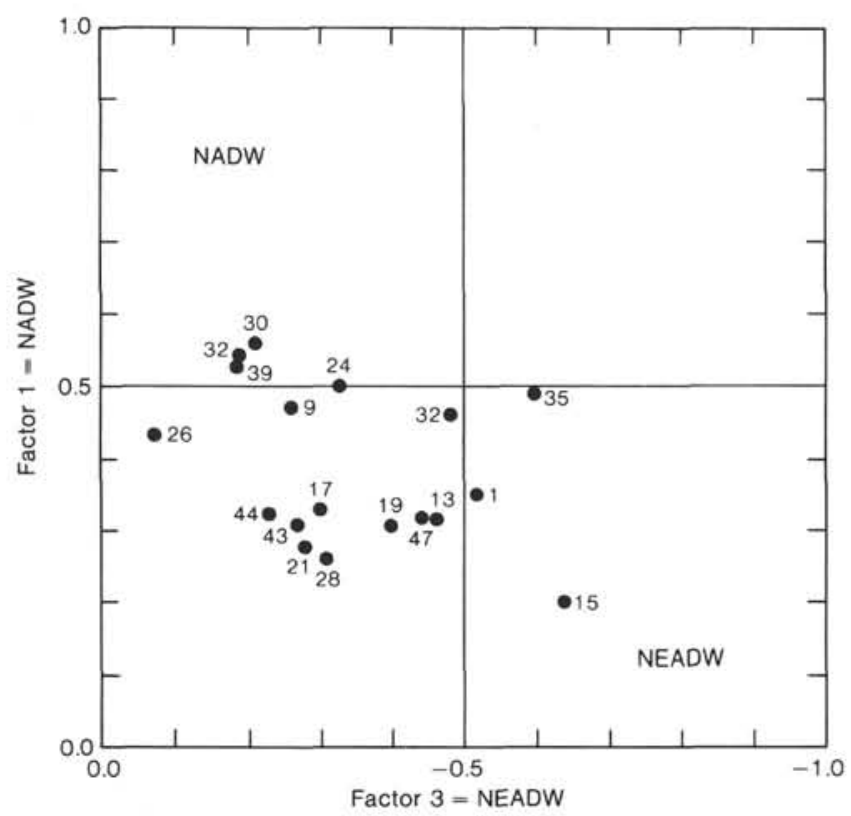

Figure 15. Hole 611C assemblages expressed in terms of varimax factors 1 and 3 of the Recent assemblages. Numbers denote corecatcher samples

modern benthic assemblages and offered helpful comment on the manuscript. I also thank Mrs. V. Ellis and Miss J. Eggins for the typing.

\section{REFERENCES}

Berger, W. H., 1982. Deep-sea stratigraphy: Cenozoic climatic steps and the search for chemo-climatic feedback. In Einsele, G., and Seilacher, A. (Eds.), Cyclic and Event Stratification: Berlin (Springer-Verlag), pp. 121-157.

Berggren, W. A., and Schnitker, D., 1983. Cenozoic marine environments in the North Atlantic and Norwegian-Greenland Sea. In Bott, M. H. P., Saxov, S., Talwani, M., and Thiede, J. (Eds.), Structure and Development of the Greenland-Scotland Ridge: New York (Plenum Press), pp. 495-548.
Blanc, P. L., and Duplessy, J. C., 1982. The deep-water circulation during the Neogene and the impact of the Messinian salinity crisis. Deep-Sea Res., 29(12A):1391-1414.

Hayes, D. E., and Frakes, L. A., 1975. General synthesis, Deep Sea Drilling Project Leg 28. In Hayes, D. E., Frakes, L. A., et al., Init. Repts. DSDP, 28: Washington (U.S. Govt. Printing Office), 919942.

Hsü, C. J., Cita, M. B., and Ryan, W. B. F., 1973. The origin of the Mediterranean evaporites. In Ryan, W. B. F., Hsü, K. J., et al., Init. Repts. DSDP, 13, Pt. 2: Washington (U.S. Govt. Printing Office), 1203-1231.

Johnson, D. A., 1982. Abyssal teleconnections: Interactive dynamics of the deep ocean circulation. Palaeogeogr., Palaeoclimatol., Palaeoecol., 38:93-128.

Keigwin, L. D., Jr., and Keller, G., 1984. Middle Oligocene cooling from the equatorial Pacific, DSDP Site 77B. Geology, 12:16-19.

Ledbetter, M. T., Williams, D. F., and Ellwood, B. B., 1978. Late Pliocene climate and south-west Atlantic abyssal circulation. Nature 272:237-239.

Matthews, R. K., and Poore, R. Z., 1980. Tertiary delta ${ }^{18} \mathrm{O}$ record and glacio-eustatic sea-level fluctuations. Geology, 8:501-504.

Murray, J. W., 1973. Distribution and Ecology of Living Benthic Foraminiferids: London (Heinemann).

1984. Paleogene and Neogene benthic foraminifers from Rockall Plateau. In Roberts, D. G., Schnitker, D., et al., Init. Repts. DSDP, 81: Washington (U.S. Govt. Printing Office), 503-529.

Phleger, F. B., Parker, F. L., and Pierson, J. F., 1953. North Atlantic Foraminifera. Rept. Swedish Deep Sea Exped., 7:1-122.

Poore, R. Z., and Matthews, R. K., 1984. Oxygen isotope ranking of late Eocene and Oligocene planktonic foraminifera: Implications for Oligocene sea-surface temperatures and global ice volume. Mar. Micropaleontol., 9:111-134.

Schnitker, D., 1974. West Atlantic abyssal circulation during the past 120,000 years. Nature, 248:385-387.

1976. Structure and cycles of the western North Atlantic bottom water, 24,000 yrs. B.P. to present. EOS, Trans. Am. Geophys. Union, 57:257-258.

1979. The deep waters of the western North Atlantic during the past 24,000 years and the re-initiation of the Western Boundary Undercurrent. Mar. Micropaleontol., 4:265-280. 1980. Quaternary deep-sea benthic foraminifers and bottom water masses. Ann. Rev. Earth Planet. Sci., 8:343-370. , 1982. Climatic variability and deep ocean circulation: evidence from the North Atlantic. Palaeogeogr., Palaeoclimatol., Palaeoecol., 40: 213-234.

Shackleton, N. J., Backman, J., Zimmerman, H., Kent, D. V., Hall, M. A., et al., 1984. Oxygen isotope calibration of the onset of icerafting and history of glaciation in the North Atlantic region. $\mathrm{Na}$ ture, 307:620-623.

Shackleton, N. J., and Kennett, J. P., 1975a. Late Cenozoic oxygen and carbon isotopic changes at DSDP Site 284: Implications for glacial history of the Northern Hemisphere and Antarctica. In Kennett, J. P., Houtz, R. E., et al., Init. Repts. DSDP, 29: Washington (U.S. Govt. Printing Office), 801-807.

1975b. Paleotemperature history of the Cenozoic and the initiation of Antarctica glaciation: Oxygen and carbon isotope analyses in DSDP Sites 277, 279, and 281. In Kennett, J. P., Houtz, R. E., et al., Init. Repts. DSDP, 29: Washington (U.S. Govt. Printing Office), 743-755.

Shackleton N. J., and Opdyke, N. D., 1977. Oxygen isotope and paleomagnetic evidence for early Northern Hemisphere glaciation. Nature, 270:216-219.

Streeter, S. S., 1973. Bottom water and benthonic foraminifera in the North Atlantic-glacial-interglacial cycles. Quat. Res., 3:131-141.

Streeter, S. S., and Shackleton, N. J., 1979. Paleocirculation of the deep North Atlantic: 150,000-yr. record of benthic foraminifera and oxygen 18. Science, 203:168-171.

Weston, J. F., and Murray, J. W., 1984. Benthic foraminifera as deepsea water-mass indicators. In Oertli, H. J. (Ed.), Benthos ' 83: Second Internat. Symp. Benthic Foraminifera (Pau, 1983): Pau (ElfAquitaine, Esso REP, and Total CFP), pp. 606-610.

Williams, C. B., 1964. Patterns in the Balance of Nature: London (Academic Press).

Date of Initial Receipt: 12 October 1984

Date of Acceptance: 26 May 1985 


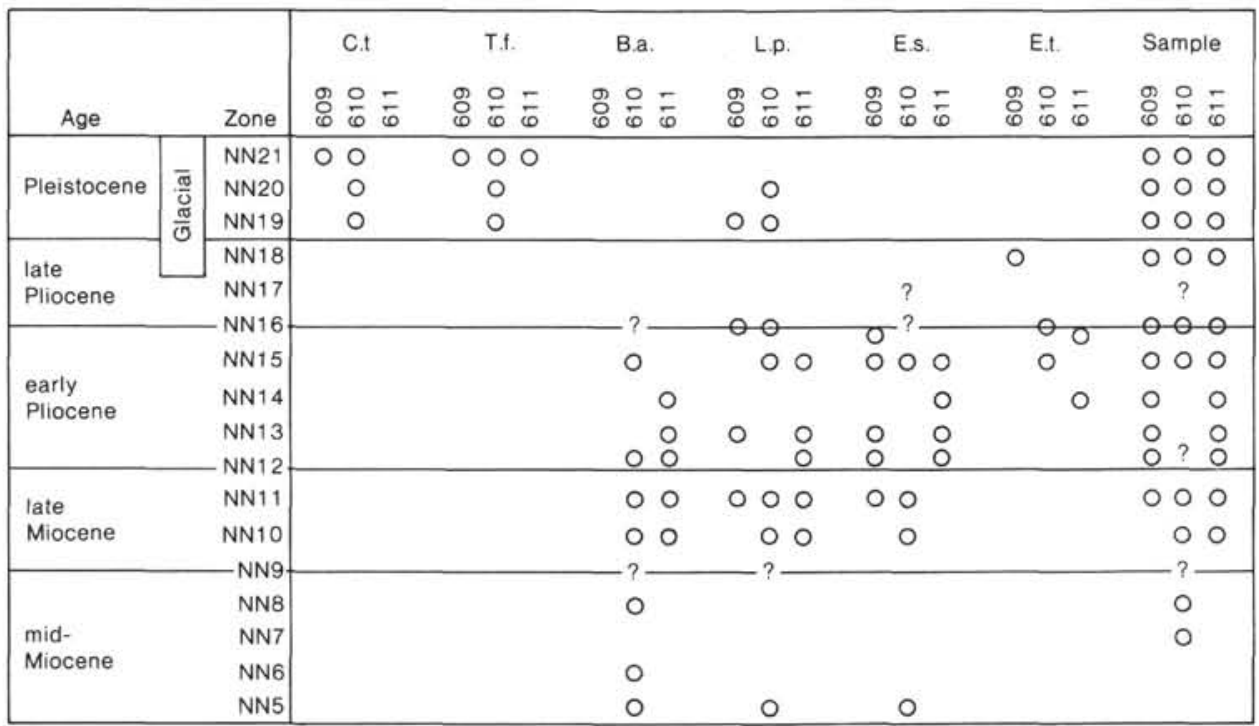

Figure 16. Species showing restricted stratigraphic distributions. C.t. = Cassidulina teretis, T.f. $=$ Triloculina frigida, B.a. = Bulimina alazanensis, L.p. = Laticarinina pauperata, E.s. = Ehrenbergina serrata , E.t. = Ehrenbergina trigona . The column headed Sample identifies those levels from which samples were available (open circle) or of uncertain age (?).

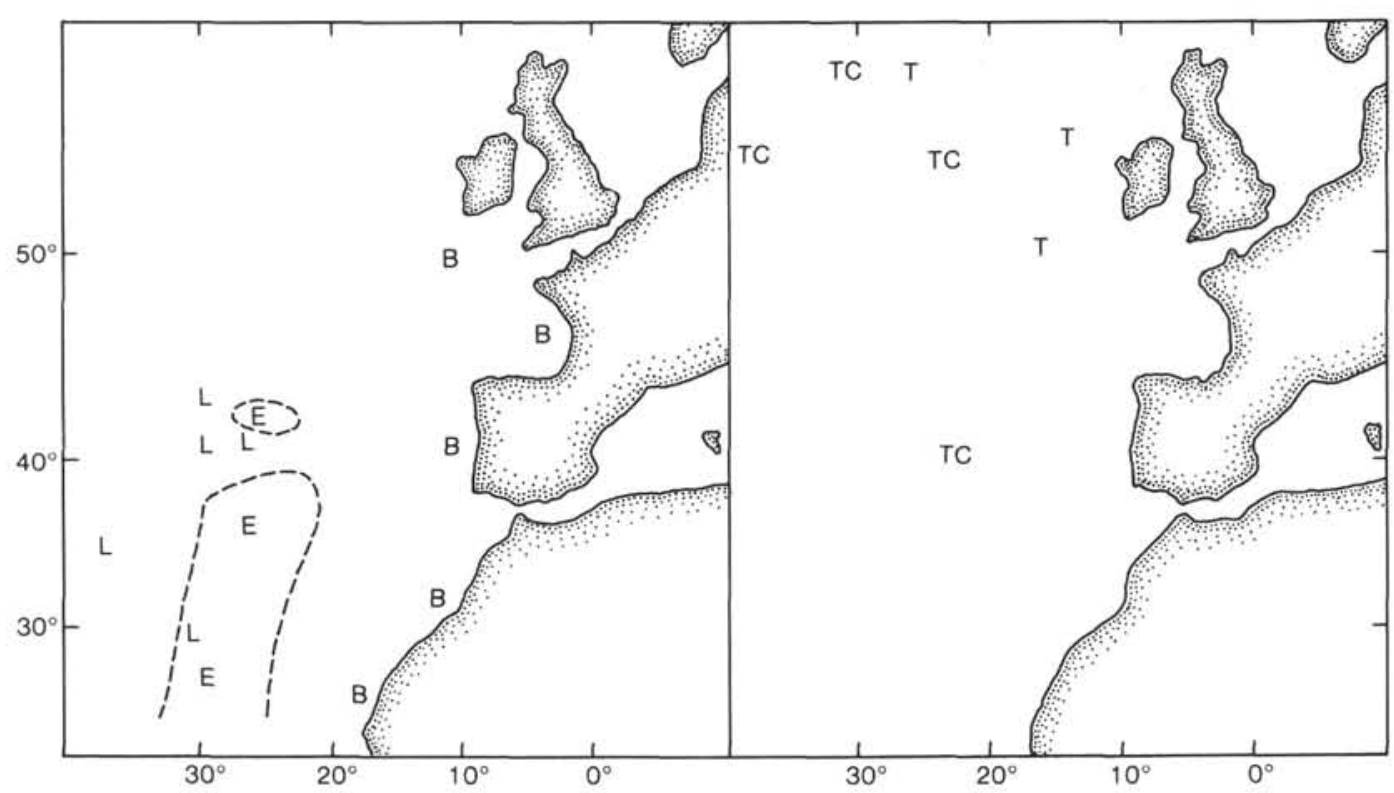

Figure 17. Distribution of selected modern species. $\mathrm{B}=$ Bulimina alazanensis, $\mathrm{C}=$ Cassidulina teretis, $\mathrm{E}=$ Ehrenbergina serrata and $E$. trigona, $\mathrm{L}=$ Laticarinina pauperata, $\mathrm{T}=$ Triloculina frigida. (Data for $\mathrm{B}, \mathrm{C}, \mathrm{E}$, and $\mathrm{T}$ from J. F. Weston, personal communication, 1983; L from Phleger et al., 1953).

\section{APPENDIX \\ Faunal Reference List}

Astrononion guadelupae $($ Parker) $=$ Melonis guadelupae Parker, 1964 Bolivina cf. thalmanni Renz, 1948

Brizalina subaenariensis $($ Cushman $)=$ Bolivina subaenariensis Cushman, 1922

Bulimina alazanensis Cushman, 1927

Bulimina striata d'Orbigny, 1843

Cassidulina obtusa Williamson, 1858

Cassidulina teretis Tappan, 1951

Cibicidoides bradyi $($ Trauth) $=$ Truncatulina bradyi Trauth, 1942

Cibicidoides kullenbergi $($ Parker) $=$ Cibicides kullenbergi Parker, 1953
Eggerella bradyi $($ Cushman $)=$ Verneuilina bradyi Cushman, 1911 Ehrenbergina serrata Reuss, 1850

Ehrenbergina trigona Goës = Ehrenbergina serrata Reuss var. trigona Goës, 1896

Epistominella exigua $($ Brady) $=$ Pulvinulina exiqua Brady, 1886

Epistominella levicula Resig, 1958

Eponides polius $\mathrm{Phleger}$ and Parker, 1951

Eponides tumidulus $($ Brady) $=$ Truncatulina tumidula Brady, 1884 Francesita advena $($ Cushman $)=$ Virgulina advena Cushman, 1922

Globocassidulina subglobosa (Brady) = Cassidulina subglobosa Brady, 1881

Hoeglundina elegans (d'Orbigny) = Rotalia elegans d'Orbigny, 1826 Laticarinina pauperta (Parker and Jones) = Pulvinulina repanda var. pauperata Parker and Jones, 1865 
Melonis barleeanus (Williamson) = Nonionina barleeana Williamson, 1858

Melonis pacificus $($ Cushman $)=$ Nonionina umbilicatula $($ Montagu) var. pacifica Cushman, 1924

Melonis pompilioides $($ Fichtel and Moll $)=$ Nautilus pompilioides Fichtel and Moll, 1798

Oridorsalis umbonatus (Reuss) = Rotalia umbonatus Reuss, 1851

Osangularia rugosa (Phleger and Parker) = Pseudoparrella(?) rugosa Phleger and Parker, 1951

Osangularia umbonifera (Cushman) = Pulvinulinella umbonifera Cushman, 1933

Planulina wuellerstorfi (Schwager) $=$ Anomalina wuellerstorfi Schwager, 1866
Pullenia bulloides (d'Orbigny) $=$ Nonionina bulloides d'Orbigny, 1846 Pullenia osloensis Feyling-Hanssen, 1954 = Pullenia quinqueloba (Reuss) subsp. minuta Feyling-Hanssen, 1954

Sigmoilopsis schlumbergeri (Silvestri) = Sigmoilina schlumbergeri Silvestri, 1904

Siphonina tenuicarinata Cushman, 1927

Siphotextularia catenata (Cushman) = Textularia catenata Cushman, 1911

Sphaeroidina bulloides d'Orbigny, 1826

Spiroplectammina spectabilis $($ Gryzbowski) $=$ Spiroplecta spectabilis Gryzbowski, 1898

Triloculina frigida Lagoe, 1977

Uvigerina compressa Cushman, 1926

Table 7. Comparison of water masses at Leg 94 holes.

\begin{tabular}{|c|c|c|c|c|}
\hline \multirow[b]{2}{*}{ Period } & \multirow[b]{2}{*}{ Zone } & \multicolumn{3}{|c|}{ Hole } \\
\hline & & $609 \mathrm{~B}$ & $610,610 \mathrm{~A}, 610 \mathrm{E}$ & $611 \mathrm{C}$ \\
\hline \multirow{3}{*}{ Pleistocene } & NN21 & “NEADW" & "NEADW" & "NEADW" \\
\hline & $\mathrm{NN} 20$ & "NEADW" & - & ? \\
\hline & NN19 & "NADW" & "NADW"/“NEADW" & "NADW" \\
\hline \multirow{2}{*}{$\begin{array}{l}\text { late } \\
\quad \text { Pliocene }\end{array}$} & NN18 & "NEADW" & - & "NEADW" \\
\hline & NN17 & $?$ & $?$ & $?$ \\
\hline \multirow{5}{*}{$\begin{array}{l}\text { early } \\
\quad \text { Pliocene }\end{array}$} & NN16 & $\begin{array}{l}\text { "NEADW" } \\
\text { "NADW" } \\
\text { "AABW" }\end{array}$ & $\begin{array}{l}\text { "NADW" } \\
\text { "NEADW" } \\
\text { "NADW" }\end{array}$ & $\begin{array}{r}\text { "NEADW" } \\
-\end{array}$ \\
\hline & NN15 & "AABW" & - & "NADW"/“AABW" \\
\hline & NN14 & "NADW"/"AABW" & $?$ & "NADW" \\
\hline & $\mathrm{NN} 13$ & "AABW" & $?$ & "AABW" \\
\hline & NN12 & "NADW" & - & $\begin{array}{l}\text { "AABW" } \\
\text { "NADW"/"NEADW" }\end{array}$ \\
\hline $\begin{array}{l}\text { late } \\
\qquad \text { Miocene }\end{array}$ & NN11 & $\begin{array}{l}\text { "AABW" } \\
\text { "AABW" }\end{array}$ & "NADW" & "NEADW"/"NADW" \\
\hline
\end{tabular}

Note: $?$ = no sample; dash $=$ no clearly defined water mass; underline $=>50 \%$ explained loading; no underline $=<50 \%$ explained loading; "NEADW" = factor 3 ; "NADW" = factor 1 ; "AABW" = factor 2 . 


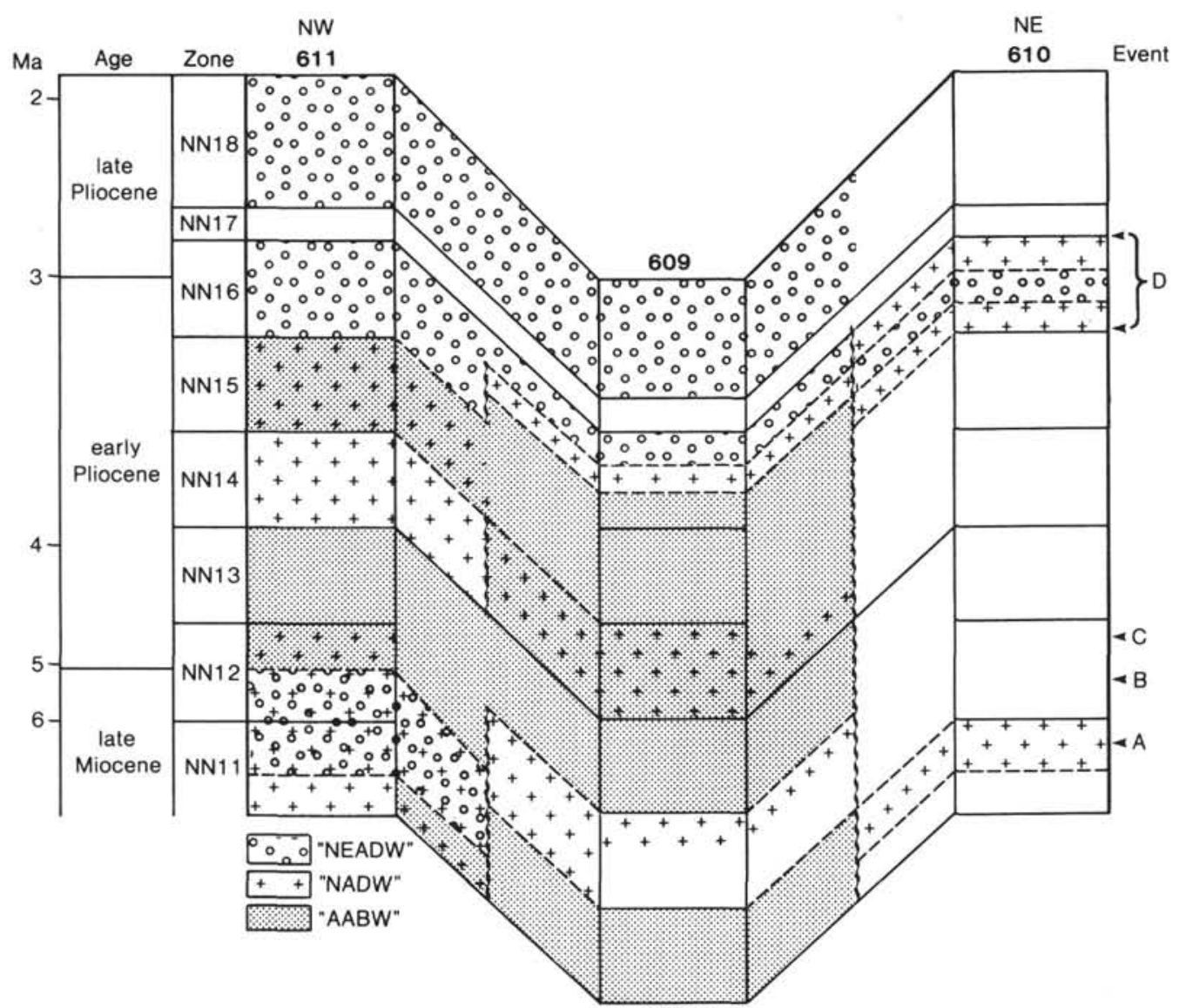

Figure 18. Diagrammatic representation of water mass distribution, in relation to biostratigraphy and major events, for the preglacial sequence. Events: $\mathrm{A}=$ maximum extent of the ice sheet in East Antarctica, $\mathrm{B}=$ Messinian salinity crisis, C = resumption of formation of "NADW," $\mathrm{D}=$ buildup of continental ice in the Northern Hemisphere. Blank areas = undefined water masses or no data.

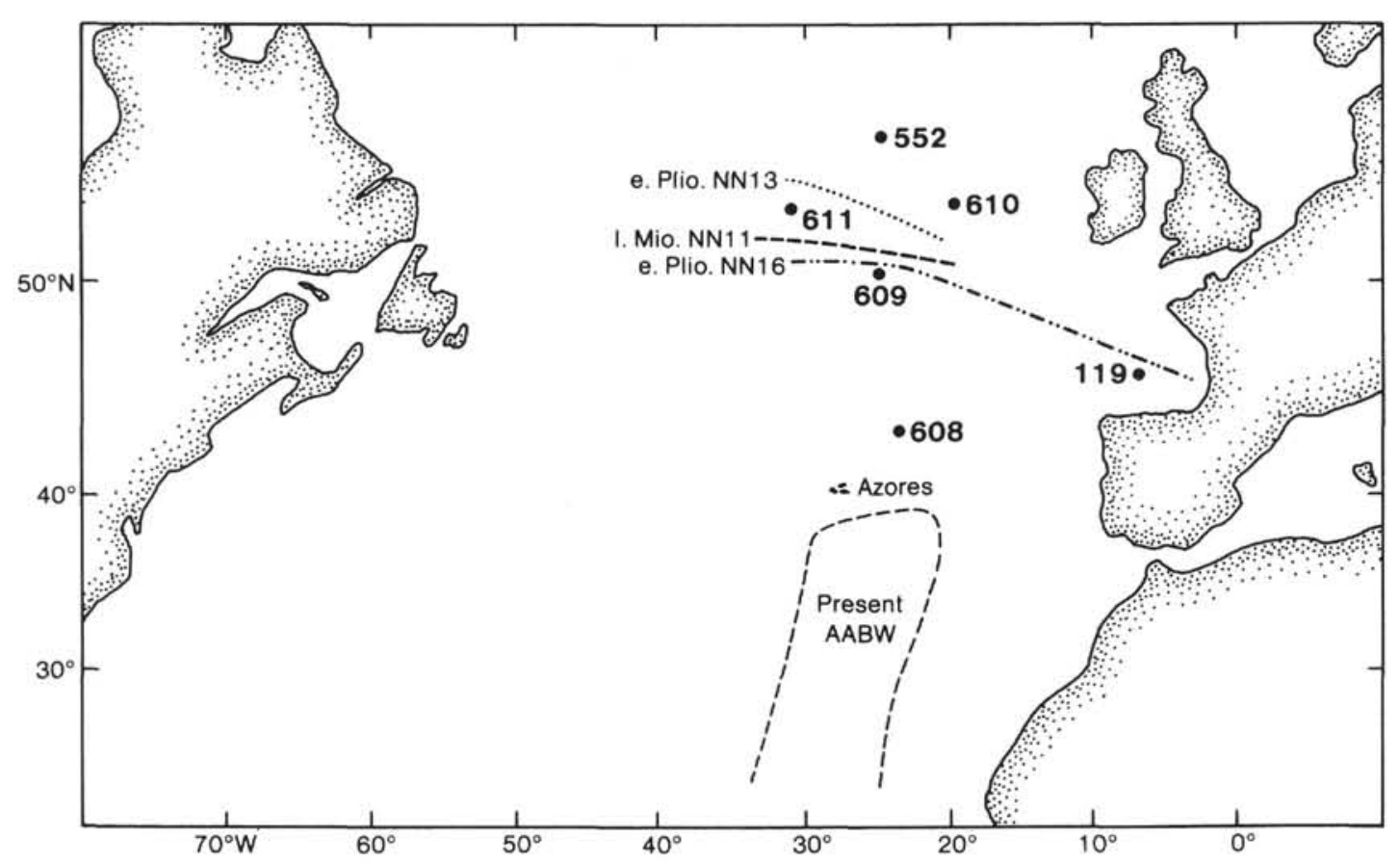

Figure 19. Changes in the northern limit of "AABW" during the late Neogene. 